\title{
The Endogeneity of Legal Regulation: Grievance Procedures as Rational Myth ${ }^{1}$
}

\author{
Lauren B. Edelman \\ University of California-Berkeley
}

Christopher Uggen

University of Minnesota

Howard S. Erlanger

University of Wisconsin-Madison

\begin{abstract}
Most accounts of organizations and law treat law as largely exogenous and emphasize organizations' responses to law. This study proposes a model of endogeneity among organizations, the professions, and legal institutions. It suggests that organizations and the professions strive to construct rational responses to law, enabled by "rational myths" or stories about appropriate solutions that are themselves modeled after the public legal order. Courts, in turn, recognize and legitimate organizational structures that mimic the legal form, thus conferring legal and market benefits upon organizational structures that began as gestures of compliance. Thus, market rationality can follow from rationalized myths: the professions promote a particular compliance strategy, organizations adopt this strategy to reduce costs and symbolize compliance, and courts adjust judicial constructions of fairness to include these emerging organizational practices. To illustrate this model, a case study of equal employment opportunity $(\mathrm{EEO})$ grievance procedures is presented in this article.
\end{abstract}

The meaning of law regulating organizations unfolds dynamically across organizational, professional, and legal fields. Legislative action and judicial interpretation offer law its official stamp, but organizations-and the

\footnotetext{
${ }^{1}$ This research was supported by grants from the National Science Foundation (SES 88-14070), the University of Wisconsin Graduate School, and the Institute of Industrial Relations at the University of California-Berkeley. The authors would like to thank Elizabeth Boyle, Frank Dobbin, Murray Edelman, Joe Galaskiewicz, David Knoke, Linda Krieger, Iona Mara-Drita, Woody Powell, Joachim Savelsberg, Kelly Shelton, Mark Suchman, John Sutton, Brad Wright, and the AJS reviewers for extremely helpful comments on earlier versions of this article. We would also like to thank Christine Hyon, Iona Mara-Drita, and Virginia Mellema for their excellent research assistance. Direct correspondence to Lauren Edelman, Center for the Study
}

(C) 1999 by The University of Chicago. All rights reserved. 0002-9602/2000/10502-0003\$02.50 
larger environmental fields in which they operate-interact with legal institutions to create ritualized ideas about what constitutes a rational response to law. It is these ideologies of rationality - the accounts, stories, and myths about how organizations should respond to law-rather than the substantive law itself that ultimately determine both organizations' strategic responses to law and the courts' responses to organizational actions.

Law, then, should be understood more as a rhetorical and symbolic resource than as an articulate mandate (Stryker 1990, 1994). The construction of law is invariably contested: many voices contribute to the process of legal enactment and vie for favorable interpretations of law once it is enacted. The more ambiguous and politically contested the law, the more open it is to social construction. Law regulating organizations is especially open to social construction because the corporate lobby is usually successful in softening regulation that infringes on corporate interests, thus producing broad, vague mandates. Under such conditions, organizations actively participate in constructing the meaning of compliance, and this construction process generates ideologies of rationality, which legitimate and reinforce particular compliance strategies. That organizations are both responding to and constructing the law that regulates them renders law "endogenous"; the content and meaning of law is determined within the social field that it is designed to regulate.

In this article, we explore the evolving ideologies of rationality within the context of equal employment opportunity (EEO) law, most notably Title VII of the 1964 Civil Rights Act, which forbids discriminatory treatment on the basis of race, color, sex, religion, or national origin. We consider in particular the interactions among organizations, the legal and personnel professions, and the courts as they construct the meaning of compliance with EEO law. Since EEO law is a particularly ambiguous and controversial area, the effects of ideologies of rationality on forms of compliance are especially visible in this case. Nevertheless, since most forms of law regulating organizations use broad language, our arguments should be applicable to other legal areas, albeit to varying degrees.

In particular, we focus on the increasing portrayal of internal EEO grievance procedures as a "rational" mode of compliance with EEO law. EEO law simply mandates nondiscrimination; it is silent as to the question of what actions an employer might take to rebut an employee's claim of discrimination. Yet, grievance procedures have emerged over the past few decades as the primary symbol of nondiscrimination and as the most rational way for employers to insulate themselves from legal liability. We use

of Law and Society, University of California, 2240 Piedmont Avenue, Berkeley, California 94720. E-mail: ledelman@uclink4.berkeley.edu 
three data sources to document the construction of ideologies of grievance procedure rationality: (1) the professional personnel literature to examine the claims of management, legal, and personnel professionals about grievance procedures; (2) survey data to study organizational creation of the procedures and their impact on complaints; and (3) federal court cases to illustrate the judiciary's construction of these procedures.

Our data suggest that the professions proffer stories about the legal value of grievance procedures to organizations and that the stories influence both organizational adoption of the procedures and legal considerations by courts. These stories are based on theories that have only tenuous legal foundation or greatly exaggerate the scope of court rulings. Nonetheless, as they are told and retold in the professional journals, the stories tend to become widely accepted in organizational fields and to influence ideas about organizational rationality across organizational, professional, and legal realms. Over time, actors in each of these realms come to equate grievance procedures with compliance, leading to the prevalent belief that organizations can avoid significant legal costs by creating these procedures.

So far, then, ours is a typically institutionalist argument. We also contend, however, that organizational ideologies of rationality induce the judiciary to incorporate grievance procedures into legal constructions of compliance with EEO law. Further, because of judicial decisions that reinforce ideologies of rationality, these procedures begin to confer tangible economic benefits on organizations. Thus what may have begun as somewhat of a stab in the dark - an educated guess modeled after the public legal order-acquires market rationality because of processes of institutionalization.

This article goes beyond previous analyses of organizational response to law (Edelman 1990, 1992; Edelman, Abraham, and Erlanger 1992; Dobbin et al. 1988; Dobbin et al. 1993; Sutton et al. 1994) in several ways. First, whereas previous studies have focused on the institutional sources of diffusion of legal structures, this study seeks to specify how the diffusion of institutional structures affects their market rationality, that is, the cost savings to organizations. Second, whereas previous studies refer to the effects of court decisions, we introduce courts (and to a lesser extent administrative agencies) as important players in the production of ideologies of rationality. Third, in contrast to institutional perspectives that do not empirically examine their assertion that institutionalized beliefs are mythical, we provide tests of the major claims about the rationality of grievance procedures that have become widely prevalent in organizational and professional communities. Finally, we trace the development of a particular ideology of rationality over time, which allows a stronger causal argument 
with respect to the interdependent roles of organizations, the professions, and the judiciary.

In the next section, we review theoretical perspectives on organizational response to law and propose a synthesis of conflicting views of rationality in the institutional and more traditional rational perspectives. Then, our argument proceeds as follows: In the section on the socially constructed rationality of grievance procedures, we sample the professional personnel literature to illustrate what we believe to be a major source of the construction of rationality in organizational fields: arguments that EEO grievance procedures are a rational response to the threat of legal intervention and that they will insulate the organization from liability for discrimination. Using data from Edelman's national survey of organizational response to civil rights law, we show how these articles correspond to a dramatic increase in organizations' adoptions of internal grievance procedures.

Next, we turn to empirical analyses of the claims spread and legitimated by the personnel profession and show that those "rational myths" have little basis in fact, at least when they are first introduced. In the section on the myth of grievance procedures as insulators, we use data from the national survey of organizations to refute the empirical claim that the use of grievance procedures would result in fewer external complaints. Then, in the section on the myth of judicial deferral to grievance procedures, we show that the law in effect at the time the early articles were written offered little support for the claim that grievance procedures would insulate organizations from liability. However, we also show that over time, as defendants in employment discrimination cases increasingly used the grievance procedure defense, courts have become more likely to defer to organizations' grievance procedures and to consider them relevant to determinations of liability. Thus, in our conclusion, we argue that the process of institutionalization has started to come full circle: Even though grievance procedures were not important in legal doctrine when the personnel profession promoted them, their significance as evidence of fair treatment has increasingly become an accepted part of the legal arsenal in discrimination lawsuits, and courts are far more likely today than they were in the past to find organizations with EEO grievance procedures not liable for discrimination. Our story, then, provides an example of the reciprocal relationship between organizational behavior and legal regulation.

\section{THEORETICAL PERSPECTIVES}

Legal rules are not self-enforcing. When a new legal rule is announced, those subject to it must determine what constitutes compliance and what 
actions they will take to demonstrate compliance (Edelman 1992). In addressing how organizations respond to law, two important analytic frameworks are a market approach, which emphasizes rational adaptation to a set of external market conditions, and an institutional approach, which emphasizes normative cues that emanate from organizations' environments. We suggest that these apparently oppositional explanations are to some extent complementary and reinforcing when the endogeneity of law is observed over time.

Market approaches emphasize organizational agency and generally hold that economic markets reward efficiency and rationality in organizational structure. These theories tend to assume that efficiency is objectively knowable and largely a product of market conditions. Because rational perspectives focus on organizations' market behaviors, law has played a relatively minor role in these analyses. And classical economic approaches address EEO law but tend to view it as an impediment to market efficiency (Epstein 1992; Posner 1986; Becker 1971). Two more recent approaches emphasize organizational adaptation to the external environment: Resource dependence theory suggests that within the constraints set by law, organizations will adopt structures that minimize costs and maximize resource flows (Pfeffer and Salancik 1978), and transaction cost approaches view law as important in shaping the relative costs of governance through contractual or hierarchical arrangements (Williamson 1979, 1981). In these accounts, then, law is one of many market forces that may affect what course of action will offer the greatest financial success. Law is understood as an exogenous phenomenon, and organizations are assumed to be rational actors with good information, attempting to operate efficiently with respect to legal constraints.

Institutional theories challenge the notion of an objective rationality, arguing that concepts of rationality are socially constructed by nonmarket factors such as widely accepted norms and patterns of behavior (Meyer and Rowan 1977; DiMaggio and Powell 1983; Scott 1983; Powell and DiMaggio 1991). Institutional accounts derive from the phenomenological work of Berger and Luckmann (1967) and highlight the taken-for-granted nature of rules. Further, these accounts hold that organizational behavior is largely given by "rational myths" or belief systems that embody stories about cause and effect and successful solutions to problems (Meyer and Rowan 1977; Zucker 1977, 1988). These belief systems appear rational in that they specify in a rulelike manner what organizations must do to be efficient, but they are myths in that their efficacy depends on the fact that they are widely shared rather than inherently correct (Scott 1987). In this view, organizations lack agency because they are shaped to such a great extent by institutionalized rules. Other institutional accounts (e.g., DiMag- 
gio 1988; Powell 1985), however, and in particular institutional studies that directly address the relation between law and organizations (e.g., Edelman 1990, 1992; Konrad and Linnehan 1995; Stryker 1994; see Suchman and Edelman [1996] for a review), tend to reject the phenomenological assumptions of the early institutionalism. These works continue to emphasize the responsiveness of organizations to their institutional environments but allow room for agency in the context of organizations' attempts to respond strategically to legal mandates. Sewell (1992) argues more generally that institutionalized schema provide resources for human agency.

The extant literature on law and organizations, then, raises the possibility of agency in organizational response to law but does not specify how institutional processes and agency might coexist. This article elaborates the institutional work on law and organizations by suggesting that organizational agency and institutional processes coexist through a process of local rationality within the context of global institutionalism: organizations seek to act rationally in response to law-to minimize costs and maximize resource flows-but the definition of rationality is constructed and evolves at the environmental level, driven by institutionalized stories about the value of particular organizational structures and actions.

There are two tenets to our argument: First, organizations seek to act rationally but are constrained by their institutional environment. For example, organizations adopt EEO grievance procedures in an effort to reduce the potential for liability, but they choose this adaptation in preference to others because grievance procedures have acquired an aura of fairness and efficacy. Second, institutional environments influence market rationality, that is, the social valuation of institutionalized structures affects their benefits to organizations. In our example, the prevalence of grievance procedures and the arguments of professionals render courts more likely to consider grievance procedures as reasonable steps toward fair treatment. Thus, the adoption of institutionalized structures often provides monetary benefits, as well as legitimacy, to organizations. This approach is decidedly institutional in that we see rationality as ultimately socially constructed. But it explicitly incorporates elements of resource dependence and transaction costs analysis by recognizing organizational efforts to adapt strategically to their legal environments (compare Oliver 1991) and by suggesting that social constructions, when recognized by the courts, render certain organizational behaviors objectively rational. Thus, institutional processes work in concert with, rather than in place of, market rationality. Over time, rational myths can become, or can at least influence, market reality. 
American Journal of Sociology

\section{THE SOCIALLY CONSTRUCTED RATIONALITY OF GRIEVANCE PROCEDURES}

In this section, we address the construction of the rationality of EEO grievance procedures during the first two decades following the passage of the 1964 Civil Rights Act. During this period, organizations were confronted with ambiguous legal mandates and the problem of defining compliance (see Edelman 1992). EEO grievance procedures gained popularity as organizations looked to one another and to the personnel and legal professions for rational solutions to this problem.

\section{The Professions' Proposal of Grievance Procedures as the Solution}

Professional networks generally play an important role in the diffusion of new forms of governance and responses to law (DiMaggio and Powell 1983; Baron, Dobbin, and Jennings 1986; Edelman et al. 1992; Jacoby 1985; Suchman 1993) and, not surprisingly, appear to have been critical in bringing grievance procedures into the legal consciousness of the organizational community. These networks consist of professional associations and their conventions, commercial workshops on how to comply with law, professional communications on the World Wide Web, and a large number of professional personnel journals.

To examine the professional construction of the rationality of EEO grievance procedures, we reviewed 85 articles in the business literature from 1964 to 1989 (personnel and management journals and law journals relevant to businesses), addressing nonunion grievance procedures in the context of EEO law. ${ }^{2}$ The authors of these articles are mostly personnel managers, management academics, or staff writers, although some are lawyers. All are intended, however, for a personnel audience. ${ }^{3}$

The articles frame the rationality of grievance procedures in several ways, which vary somewhat over time. In the late 1960s, articles that mentioned grievance procedures tended to focus on their benefits for avoiding unions (e.g., Corzine 1967), but by the early 1980s, the professions had turned their attention to avoiding legal problems and in particu-

\footnotetext{
${ }^{2}$ The articles were collected by the first author as part of her larger project on organizations' EEO practices. An undergraduate assistant searched all issues of 10 major professional personnel journals during 1964-89 and identified articles addressing grievance procedures. For this study, we chose the articles that addressed grievance procedures in the context of EEO law.

${ }^{3}$ Although some are written about the value of general grievance procedures applied to EEO matters rather than about EEO grievance procedures specifically, the quotations below show the types of claims that members of the personnel, legal, and management professions make about the rationality of grievance procedures generally.
} 
lar to compliance with civil rights law. During this period, the articles emphasize (and arguably inflate) the threat of civil rights lawsuits and claim that organizations can substantially reduce both the number of such lawsuits and the potential for liability should lawsuits occur by creating internal grievance procedures. The articles generally hold that grievance procedures reduce lawsuits and complaints to external agencies by resolving claims internally, reduce liability by demonstrating compliance, reduce discrimination by providing information and locating management problems, reduce the appeal of unions by providing due process without dues, and raise morale by giving employees voice. ${ }^{4}$

Two specific assertions about the legal value of grievance procedures emerged during this period: first, internal grievance procedures help to resolve employee complaints so that employees would have no need to file charges with external EEO agencies; and second, if external complaints were filed, courts would look favorably on organizations that had taken steps to provide internal due process. The latter claim was made most often in connection with discussions of sexual harassment claims. For example, a 1981 article in Personnel, written by a lawyer and a management professor, begins with a blurb above the title stating, "Employers can protect themselves against liability for sexual harassment charges with a strong policy against such activity and a grievance procedure that expedites the processing of such complaints" (Linenberger and Keaveny 1981, p. 60). The article goes on to state, "If the employer has no knowledge of the harassment, liability can be avoided if two conditions have been met: (1) The employer has a policy discouraging sexual harassment, and the employee failed to use an existing grievance procedure; and (2) the sexually harassing situations are rectified as soon as the employer becomes aware of them" (Linenberger and Keaveny 1981, p. 60). In fact, as we point out below, there was very little legal support for this argument in 1981.

The personnel journals emphasize the advantages of internal grievance procedures for insulating organizations from liability, but they also suggest internal benefits: Grievance procedures provide a sense of justice to employees and will therefore improve morale and productivity. David Ewing, a managing editor of the Harvard Business Review, ties these themes together in a 1982 article in that journal.

\footnotetext{
${ }^{4}$ It is not just articles written about grievance procedures that emphasize their value. Virtually all articles that address civil rights law or civil rights issues mention the value of grievance procedures; moreover, we have never encountered an article that recommends that employers not have a grievance procedure. Other forums, such as commercial workshops on human resources issues and Web sites addressing human resource audiences also frequently recommend the adoption of grievance procedures.
} 
American Journal of Sociology

An effective form of due process has various advantages for a company. It helps to clear the air so that rumors of an abusive discharge or unfair handling of an objector do not circulate and build up and sometimes, in the end, create a worse situation than the original event. It is valuable for morale. . . . Also, attorneys with whom I have talked believe that an in-company hearing procedure can be helpful in case the employee objector takes the company to court; that is, evidence that an objector has been turned down in a fair hearing will be admitted into a legal proceeding. (Ewing 1982, p. 121; emphasis added)

Articles frequently emphasize the significant cost savings available to organizations that institute internal grievance procedures. A 1984 article, written by a lawyer and published in Management Review contains the following advice: "A good grievance procedure keeps problems within the company. It encourages fair treatment. Most importantly, it deters employees from seeking representation by outsiders-unions, government agencies (like the EEOC or OSHA) or even lawyers. A problem settled in-house can save tens of thousands in litigation costs" (Panken 1984, p. 42).

A 1985 article also points to the value of grievance procedures for avoiding employee lawsuits in the first place. The author, an investigative reporter, writes, "If an employee can get a fair hearing through a grievance system, there is less chance this employee will be tempted to go to the courts" (Condon 1985, p. 72).

By the mid-1980s, then, the theme that grievance procedures could internalize disputes and gain favor with courts appears to be well established in the professional literature. Grievance procedures had become widely accepted as a rational form of compliance with civil rights law and as a rational form of managing internal disputes. The question of why the professions advocate particular solutions to legal problems is an important one that we do not address directly in this article. But the professions' literature offers a number of explanations, including professions' battles of jurisdictions (Abbott 1988; Larson 1977) and their efforts to establish power within organizations (Pfeffer 1981; Edelman et al. 1992).

\section{Organizations' Adoption of EEO Grievance Procedures}

The rationalization of grievance procedures is not simply an artifact of the personnel and legal professions; it is evidenced by the practices of organizations as well. In this section, we use data from Edelman's nationwide survey of EEO practices, conducted in 1989, to examine the adoption patterns of EEO grievance procedures (see Edelman [1992] for a discussion of the sample and response rates). As shown in table 1, of 346 organizations, $107(31 \%)$ had created grievance procedures explicitly designed 
Grievance Procedures

TABLE 1

Descriptive Statistics on the Creation of Discrimination Grievance PROCEDURES

\begin{tabular}{|c|c|c|c|c|}
\hline & Government & College & Business & Total \\
\hline \multicolumn{5}{|l|}{$\begin{array}{l}\text { No. }(\%) \text { of organizations creating specific } \\
\text { grievance procedures:* }\end{array}$} \\
\hline 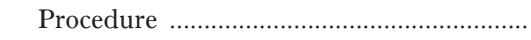 & $22(45)$ & $22(44)$ & $63(26)$ & $107(31)$ \\
\hline 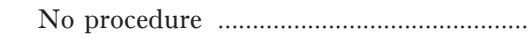 & $27(55)$ & $28(56)$ & $184(74)$ & $239(69)$ \\
\hline 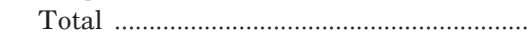 & 49 & 50 & 247 & 346 \\
\hline \multicolumn{5}{|l|}{$\begin{array}{l}\text { The creation of specific grievance proce- } \\
\text { dures by time period: } \uparrow\end{array}$} \\
\hline Before 1970 & $2(10)$ & $2(10)$ & $10(22)$ & $14(16)$ \\
\hline 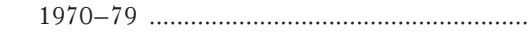 & $11(55)$ & $11(52)$ & $11(24)$ & $33(38)$ \\
\hline $1980-90 \dagger \ldots \ldots$ & $7(35)$ & $8(38)$ & $24(53)$ & $39(45)$ \\
\hline 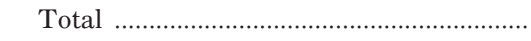 & 20 & 21 & 45 & 86 \\
\hline \multicolumn{5}{|l|}{$\begin{array}{l}\text { No. }(\%) \text { of organizations creating specific } \\
\text { grievance procedures-mail sample } \\
\text { only: } \ddagger\end{array}$} \\
\hline 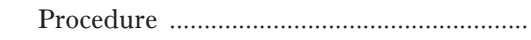 & $16(47)$ & $15(48)$ & $29(20)$ & $60(29)$ \\
\hline 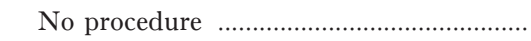 & $18(53)$ & $16(52)$ & $113(80)$ & $147(71)$ \\
\hline 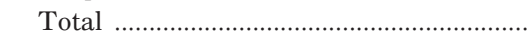 & 34 & 31 & 142 & 207 \\
\hline \multicolumn{5}{|l|}{ 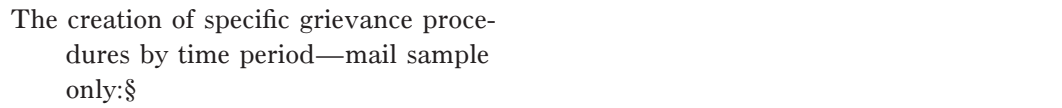 } \\
\hline Before 1970 & $1(6)$ & $2(13)$ & $3(13)$ & $6(11)$ \\
\hline 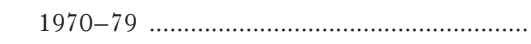 & $9(56)$ & $7(47)$ & $7(29)$ & $23(42)$ \\
\hline $1980-89 \dagger \ldots \ldots$ & $6(38)$ & $6(40)$ & $14(58)$ & $26(47)$ \\
\hline Total & 16 & 15 & 24 & 55 \\
\hline
\end{tabular}

* Between 1987 and 1990, 16 organizations created procedures. These organizations were coded as not having a procedure in analyses predicting complaints in 1986.

$\dagger$ Dates of the creation of specific procedures were not available to 21 cases. For the event history analyses, these cases are omitted.

\$ Between 1987 and 1990, 12 organizations created procedures. These organizations were coded as not having a procedure in analyses predicting complaints in 1986.

$\S$ Dates of the creation of specific procedures were not available for five cases. These cases are omitted for the event history analyses.

to handle discrimination-related complaints by 1989. Of the 86 for which creation dates were available, $14(16 \%)$ were created before 1970, $33(38 \%)$ were created between 1970 and 1979, and $39(45 \%)$ were created between 1980 and $1989 .{ }^{5}$

${ }^{5}$ Fig. 1 also shows the creation patterns for the 207 organizations that responded to the follow-up mail survey. The mail follow-up is discussed in more detail later in the section on the myth of grievance procedures as insulators. Analyses of complaints shown in later tables are based on the mail sample only. 
Figure 1 shows an integrated hazard plot, which illustrates the pattern of adoption of these procedures over time. ${ }^{6}$ The plot shows little change in the formation rate until about 1976, a time of relatively strong civil rights enforcement, and reflects a rapid diffusion of these structures during the 1970s. The adoption rate remains fairly high during the 1980s despite the weaker civil rights enforcement of the Reagan era. This suggests that rational myths, as much as enforcement threats, were motivating the diffusion process by this period. In fact, there appears to be a second burst of EEO grievance procedure creation in the second half of the 1980s.

\section{Why Is the Grievance Procedure Solution Attractive to Organizations?}

Market-based approaches to organizational behavior would attribute the evolution of EEO grievance procedures to the market efficiency of these practices; like the personnel professionals, they would tend to see these procedures as valuable for employee morale and for minimizing legal risk (Thompson 1967; Pfeffer and Salancik 1978; Williamson 1975). The institutional literature, however, would attribute the evolution of EEO grievance procedures to the construction of rational myths or stories about the rationality about these procedures (Meyer and Rowan 1977; Scott and Meyer 1983; DiMaggio and Powell 1983). One of the key features of rational myths is that they appear so obvious that no one questions their veracity; they just seem right.

Our contention is that these myths originate from models that have already been institutionalized in other social arenas but that, over time, they influence law and, hence, market forces. In the case of grievance procedures, the institutionalized source of the myth is the legal order. Grievance procedures appear rational because they look like the system of appeals available in the public legal process, a basic and well-institutionalized feature of a legitimate normative order (see Edelman 1990). Since civil rights law is essentially a mandate of fair treatment for employees, regardless of race, sex, religion, or national origin, it seems only natural-and it is taken for granted-that grievance procedures, as the symbolic embodiment of due process, would in fact provide fair treatment. And therefore, it is taken for granted that the courts, society, and employ-

\footnotetext{
${ }^{6}$ Integrated hazard functions provide a nonparametric estimate of the integral of the hazard rate. Although the adoption rate is not directly observable, the hazard rate can be calculated based on the proportion of organizations at risk of experiencing an event at any given point in time that do in fact experience the event. The area under the curve represents the cumulative probability that organizations will create EEO grievance procedures. Changes in the slope of the center line reflect changes in the rate of EEO grievance procedure creation. The upper and lower lines represent the $95 \%$ confidence interval.
} 


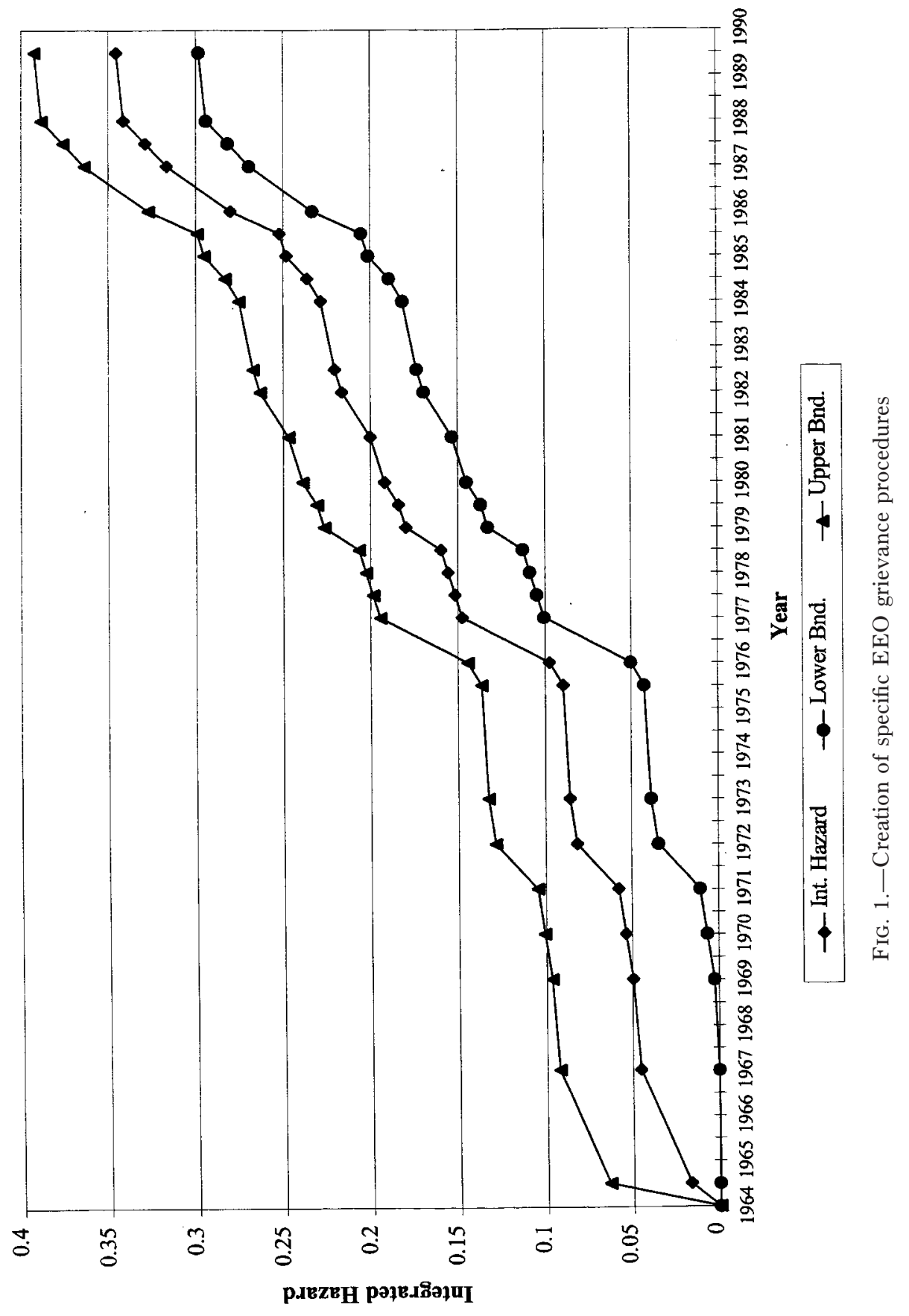


ees would in fact recognize that grievance procedures constitute an effort to comply with civil rights law.

Event-history analyses of the diffusion patterns of EEO grievance procedures show that, consistent with institutional theory, attributes of the institutional environment rather than internal technical concerns drive the diffusion of EEO grievance procedures (compare Edelman 1990, 1992; Mezias 1990; Sutton et al. 1994). These analyses (shown in the appendix) reveal that, consistent with institutional theory, organizations with the highest rates of EEO grievance procedure creation were those closest to the public sphere (both government organizations and colleges are more than twice as likely as business organizations to create EEO grievance procedures). Furthermore, organizations with affirmative action offices were more likely to create EEO grievance procedures than those without, suggesting that these offices availed themselves of the professional literature recommending internal grievance procedures. Thus, the event-history analyses, which show a diffusion of grievance procedures, support our argument that there was a gradual institutionalization of the "rational myth" that internal grievance procedures would insulate organizations from their legal environments.

But how do we know that the "rational myths" circulated by the personnel profession, and apparently adopted by organizations, are not in fact "reality"? If EEO grievance procedures in fact produce efficiency benefits for organizations, then market-based theories would be largely correct. To answer this question, it is first worth noting that many of the claims we found in the personnel journals were based on generalizations from the experience of single personnel managers, or simply on suppositions. ${ }^{7}$ As a result, it is impossible to trace the authority for these statements or to determine whether they are well-founded (see Galanter 1983, 1994). ${ }^{8}$

\footnotetext{
${ }^{7}$ As found in a study of the professional construction of wrongful discharge (Edelman et al. 1992), it is quite common for such claims to lack any references to those studies or authorities backing up their conclusions. Consider the following 1985 article by an associate editor of Personnel, published by a division of the American Management Association: "According to recent surveys, the number of lawsuits initiated against firms by former or current employees [has] been steadily increasing over the past few years, along with the number of organizations that have instituted formal grievance procedures for nonunion workers. There are good reasons for organizations to institute these procedures: (1) to ensure fair treatment of employees across the board, (2) to raise morale in the workplace, and (3) to avoid costly court litigation" (Lo Bosco 1985, p. 61). Following the standard practices of journals of this type, this article provides no references to these "recent surveys," and we were unable to find any.

${ }^{8}$ In an article on discourse about lawyers, Galanter (1994, p. 664) calls attention to "a series of factoids or macro-anecdotes about litigation [that] became the received wisdom." Galanter (1983, p. 61) argues that knowledge "is not the mechanical recording of something out there-it is an interpretation of what we encounter, informed by our hopes and fears and by our pictures of how the world is."
} 
Although we do not maintain that the claims of the professions are entirely wrong, we suggest that the professions' arguments often have little factual basis and are sometimes greatly exaggerated. We base our argument on an empirical examination of the two common claims in the personnel literature: First, that organizations with internal grievance procedures will experience fewer claims to external EEO agencies; and second, that courts will be less likely to find organizations in violation of civil rights law if they have an internal grievance procedure in place. The next two sections show that these claims were largely myth at the time they were formulated. In that sense, they provide evidence for institutional accounts of rationality. But we also show that over time certain economic benefits begin to accrue to organizations that adopt these procedures. Thus, EEO grievance procedures turn out to have some market-based rationality, although that rationality is socially constructed.

\section{THE MYTH OF GRIEVANCE PROCEDURES AS INSULATORS}

As exemplified in the articles discussed above, a major appeal of EEO grievance procedures is their perceived capacity to internalize complaints, thus buffering the organization from complaints to external agencies and from lawsuits. To test this claim, we measure organizations' propensity to elicit both external and internal complaints, focusing in particular on the effects of EEO grievance procedures. We consider three ways in which the presence of EEO grievance procedures may affect the volume of discrimination complaints.

First, if special EEO grievance procedures reduce the likelihood of lawsuits, they must reduce the likelihood of complaints to external fair employment agencies, which employees must file as a first step in pursuing their statutory rights under Title VII and several other civil rights statutes. Thus, one measure of the efficacy of special EEO grievance procedures is their impact on the number of external complaints.

Second, the presence of an internal grievance procedure may in fact generate complaints that would not have been voiced were external complaint forums the only option. EEO grievance procedures may generate internal complaints by providing an alternative forum, which employees may see as less expensive, more accessible, or less likely to result in retaliation than external forums. Thus, the second effect of EEO grievance procedures we consider is the effect of those procedures on the overall number of internal complaints.

Third, EEO grievance procedures may also generate external complaints by making employees more aware of their rights or by encouraging internal complaints but then failing to provide satisfactory resolutions. This may motivate employees to file external complaints where they 
would not have done so otherwise. To fully understand the dynamics of internal grievance procedures, then, it is necessary to assess the likelihood that complaints will be internalized, controlling for the overall volume of complaints. Thus, for our third measure of the efficacy of EEO grievance procedures, we estimate the effects of EEO grievance procedures on the ratio of internal to total complaints. This "internalization ratio" may represent the diversion of complaints from the external legal system. Alternatively, it may simply reflect an increase in different types of complaints, which employees are more likely to pursue in internal forums.

Some of the effects of a special EEO grievance procedure on the volume of internal and external complaints, and on the internalization ratio, may be influenced (or supplanted) by a general internal grievance procedure (i.e., one that is not specifically designated for discrimination-related complaints). Although we specified models estimating the effects of general grievance procedures as well, in this article we focus on special EEO grievance procedures because we expect that much of the impact of special EEO grievance procedures is due to their symbolic rather than their functional value. Special EEO grievance procedures tend to encourage internal vis-à-vis external complaints because they signal a commitment to fair treatment and to the resolution of discontent.

The volume of discrimination complaints is, of course, likely to be a function of a number of factors other than whether there is an EEO grievance procedure in place. Indeed, since employees are likely to be responsive to their employers' symbolic actions (Fuller 1993) and to their institutional environments, many of the factors that encourage responsiveness to legal norms among managers may also motivate complaints and lawsuits. Employees may be more likely to mobilize their rights in an organizational culture that encourages attention to law than in a highly repressive or discriminatory culture. Thus, we expect that factors that render organizations more sensitive to their legal environments (sector and contractor status), and the presence of internal offices and staff that demonstrate attention to civil rights law (EEO offices and the presence of an EEO counselor), will increase the overall volume of complaints, both external and internal. The presence of other internal structures is likely to be particularly important since these structures tend to generate agendas that foster attention to EEO ideals (Edelman et al. 1991; Edelman and Petterson 1999). EEO office staffs and counselors may develop commitments to EEO goals and encourage employees to challenge discrimination (Edelman et al. 1991). Further, EEO office staff and counselors are likely to encourage the use of internal procedures because they believe in their capacity to reduce external complaints and lawsuits. Finally, internal counselors increasingly see complaint resolution as a good management technique and may encourage the use of internal EEO grievance procedures 
for that reason (Edelman, Erlanger, and Lande 1993). The percentage of female and minority employees in an organization may also affect the volume of complaints by altering the internal culture of the organizations. A greater proportion of minorities and women increases employers' opportunity for discrimination and may sensitize employees to their collective status and rights.

Another factor that would likely affect the volume of discrimination complaints is, of course, the actual amount of discrimination in the organization. We do not have a direct measure of discrimination, and given legal ambiguity as to what constitutes discrimination, it would indeed be quite difficult to find one. Prior discrimination lawsuits could serve as a proxy for discrimination. Just as complaints, however, prior lawsuits (which must originate as external complaints) are likely to be a product of the organization's legal environment and internal legal culture. In addition, organizations may change their behavior after being subject to a suit. Thus, although we examine the effect of prior discrimination lawsuits on complaints, we note that it is impossible to disentangle the possible explanations for the observed effects. Perhaps a better proxy for discrimination would be the sector and contractor status variables. Economists consistently note greater responsiveness to civil rights law (measured by the workforce shares of minorities and women) in the public sector and among federal contractors (Leonard 1984, 1986; Heckman and Wolpin 1976). If there is less actual discrimination closer to the public sphere, then one would expect fewer discrimination complaints in those sectors. However, if, as we suggest, the heightened responsiveness of organizations in these sectors creates a culture more conducive to rights-consciousness, then one would expect an increase in complaints in those sectors. Clearly, both factors may be at work, which could temper the observed differences in complaint volume among the sectors.

Although the factors above are of primary interest, we also consider the effects of other organizational attributes that may affect organizations' propensities to evoke complaints. We consider organizational size, since larger organizations will produce more complaints. Organizational age could affect complaints if organizational culture is imprinted at the time of the organization's birth. Professionalization may increase discrimination complaints both because of a greater awareness of legal rights and greater subjectivity in promotions and hiring. The presence of a personnel office, the number of attorneys who handle EEO matters, and the presence of a union could also increase awareness of legal rights. Several other environmental variables may also be relevant: in particular, we consider geographic region (South vs. other) and whether the organization is in a manufacturing or service sector.

The data for these analyses come from a mail follow-up survey con- 
ducted as part of Edelman's 1989 EEO survey. ${ }^{9}$ Approximately twothirds, or 207, of the original 346 respondents returned the mail questionnaire. The mail survey asked for data on internal and external complaints for 1986. The year 1986 was chosen because it was sufficiently close to the survey date to permit accurate recall, yet sufficiently prior to the survey for organizations to know whether external complaints had been filed. If organizations did not have data for 1986 but did know the number of complaints for another recent year, they were asked to provide that information instead, and a few organizations provided information for a year before or after 1986.

These data clearly provide only rough indicators, especially with respect to internal complaints, where organizations may have different criteria for recording a complaint. Further, any data on the timing of complaints may be problematic because it is difficult to know when complaints, external or internal, will affect organizations. Employers and personnel professionals may be aware of a developing case, for example, long before any complaint is filed. Or knowledge of one complaint may lead to more informal complaints at lower levels of an organization, which might not be officially recorded. However, the data on the relative frequency of internal and external complaints are, to our knowledge, unique and provide an important indicator of a phenomenon that is both theoretically and socially important. ${ }^{10}$

Because the theoretical construct we measure is organizations' propensity to evoke complaints, we estimate maximum likelihood Tobit models. Tobit analysis is appropriate where the dependent variable is censored at some upper or lower bound as a result of the way the data are collected (Winship and Mare 1992; Tobin 1958; Maddala 1983; Roncek 1992). In our case, we have censoring at a lower bound: an organization's propensity to elicit complaints could be less than zero since an organization, given

\footnotetext{
${ }^{9}$ The survey, Organizational Response to EEO/AA Law, was supported by a grant from the National Science Foundation (SES 88-14070) and is described in appendix A of Edelman (1992).

${ }^{10}$ Five variables were missing information for $0.5 \%-7 \%$ of the sample. We created missing data indicator variables (coded as " 1 " if missing, "0" if observed) for each of these variables and recoded the original indicators to the variable mean (Little and Rubin 1987). None of the missing value indicator variables are statistically significant in any of the models presented below, suggesting that organizations missing information on these measures do not have different rates of complaints than organizations with complete data. If the organization knew that it had a specific procedure, but did not know the year it was created, we assume that the procedure was in place in 1986. To test this assumption, we estimated models that included a dummy variable coded " 1 " if the year was unknown and "0" if known. This coefficient was also not significant and close to zero in magnitude.
} 
its environment, structure, and internal legal culture, may discourage complaints as well as produce or encourage complaints. Since a majority of the organizations experienced no complaints in the survey year, the distribution of the dependent variables is skewed and least squares regression would produce biased and inconsistent estimates. We, of course, only observe the portion of the distribution that is zero or greater. ${ }^{11}$ Thus, we estimate models of the form:

1. $\mathrm{Y} * 1_{\mathrm{i}}=\mathrm{X}_{\mathrm{i}} \mathrm{B}+\mathrm{e}_{\mathrm{i}}$,

2. $\mathrm{Y} 1_{\mathrm{i}}=\mathrm{Y} * 1_{\mathrm{i}}$ if $\mathrm{Y} * 1_{\mathrm{i}}>0$,

3. $\mathrm{Y} 1_{\mathrm{i}}=0$ if $\mathrm{Y} * 1_{\mathrm{i}} \leq 0$,

where, for the $i$ th observation, $\mathrm{Y} * 1_{\mathrm{i}}$ represents an organization's propensity to evoke complaints (the unobserved continuous latent variable), $\mathrm{Y} 1_{\mathrm{i}}$ represents observed complaints; $\mathrm{X}_{\mathrm{i}}$ is a vector of values on the independent variables, $e_{i}$ is the error, and $B$ is a vector of coefficients. We assume that $\mathrm{e}_{\mathrm{i}}$ is uncorrelated with $\mathrm{X}_{\mathrm{i}}$ and is independently and identically distributed (Winship and Mare 1992; Roncek 1992). Below we discuss Tobit models predicting the volume of complaints to external agencies, internal complaints, and the internalization ratio, in turn. Tobit coefficients are difficult to interpret because they capture two types of effects in a single estimate. We use Roncek's method (1992; see also McDonald and Moffitt 1980; Caspi et al. 1998) to partition these estimates into a component for the change in the probability of experiencing a complaint (among cases with zero complaints) and a component predicting the number of complaints (among organizations with at least one complaint). Table 2 shows the variables used in our analyses as well as descriptive statistics for those variables.

The most direct measure of the buffering capacity of EEO grievance procedures is their relationship to the volume of complaints to external fair employment agencies. Table 3 shows a Tobit model predicting the volume of complaints to these external agencies. To provide the strongest test of the buffering hypothesis posited by the legal and personnel professions, we construct the EEO procedure indicator as a dummy variable, coded "1" for organizations that have a specific EEO grievance procedure and " 0 " for organizations that have either no procedure or a general griev-

\footnotetext{
${ }^{11}$ The variable could also be conceptualized as a simple count, making Poisson regression the appropriate analysis technique. For all of our analyses, Poisson regression produces similar results, albeit with coefficients and $t$-values of greater magnitude. We think the Tobit results are more realistic, and they are in any case more conservative. OLS regressions also produced similar results.
} 
TABLE 2

Complaint Analysis: Variables, Descriptive Statistics, and Variable DEFINITIONS

\begin{tabular}{|c|c|c|c|}
\hline Variables & Mail Mean & $\begin{array}{l}\text { Phone } \\
\text { Mean }\end{array}$ & Description \\
\hline \multicolumn{4}{|l|}{ Fixed independent variables:* } \\
\hline Business ..................................... & $.71(.45)$ & $.69(.47)$ & Private firm \\
\hline College & $.14(.35)$ & $.15(.36)$ & College or university \\
\hline Government ............................ & $.14(.35)$ & $.16(.37)$ & Government agency \\
\hline 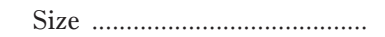 & $7.03(15.2)$ & & Employees in hundreds (1984) \\
\hline Log size & $5.57(1.52)$ & $5.58(1.54)$ & $\begin{array}{l}\text { Natural log of full-time em- } \\
\text { ployees (1989) }\end{array}$ \\
\hline 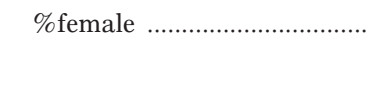 & $.46(.25)$ & & $\begin{array}{l}\text { Percentage of full-time perma- } \\
\text { nent employees that are } \\
\text { women (1984) }\end{array}$ \\
\hline$\%$ minority & $.17(.19)$ & & $\begin{array}{l}\text { Percentage of full-time employ- } \\
\text { ees that are members of ra- } \\
\text { cial or ethnic minority } \\
\text { groups }\end{array}$ \\
\hline 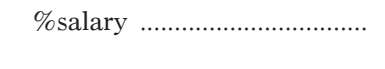 & $.42(.28)$ & $.41(.28)$ & $\begin{array}{l}\text { Percentage of full-time employ- } \\
\text { ees that are salaried }\end{array}$ \\
\hline South & $.32(.47)$ & $.32(.47)$ & " 1 " if South, " 0 " if other \\
\hline \multicolumn{4}{|l|}{$\begin{array}{l}\text { Changing independent } \\
\text { variables:* }\end{array}$} \\
\hline 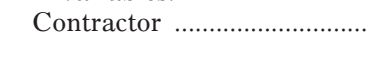 & $.35(.48)$ & $.38(.49)$ & $\begin{array}{l}\text { Federal contractor subject to } \\
\text { OFCCP regulation }\end{array}$ \\
\hline 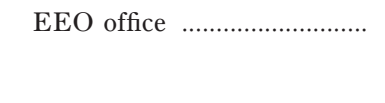 & $.17(.38)$ & $.17(.38)$ & $\begin{array}{l}\text { A separate department for } \\
\text { equal employment opportu- } \\
\text { nity or affirmative action }\end{array}$ \\
\hline 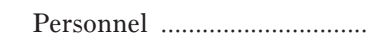 & $.73(.44)$ & $.72(.45)$ & Personnel department \\
\hline 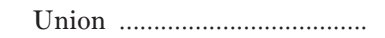 & $.41(.49)$ & $.44(.50)$ & Partially or fully unionized \\
\hline 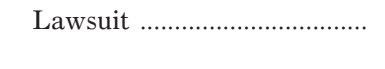 & $.26(.44)$ & $.27(.44)$ & $\begin{array}{l}\text { Past suit for discrimination- } \\
\text { related complaint }\end{array}$ \\
\hline \multicolumn{4}{|l|}{ Fixed dependent variables:* } \\
\hline Internal $\dagger \ldots \ldots \ldots \ldots$ & $1.56(3.25)$ & & $\begin{array}{l}\text { Number of EEO-related com- } \\
\text { plaints filed through the or- } \\
\text { ganization's internal com- } \\
\text { plaint procedure (1986) }\end{array}$ \\
\hline External $\dagger \ldots \ldots \ldots$ & $1.41(3.09)$ & & $\begin{array}{l}\text { Number of EEO-related com- } \\
\text { plaints filed with the EEOC } \\
\text { or state agency (1986) }\end{array}$ \\
\hline 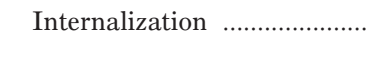 & $.51(.36)$ & & $\begin{array}{l}\text { Ratio of internal to total com- } \\
\text { plaints (1986) }\end{array}$ \\
\hline \multicolumn{4}{|l|}{$\begin{array}{l}\text { Changing dependent/indepen- } \\
\text { dent variable:* }\end{array}$} \\
\hline EEO procedure …….............. & $.27(.44)$ & $.24(.43)$ & $\begin{array}{l}\text { Specific equal employment op- } \\
\text { portunity grievance pro- } \\
\text { cedure }\end{array}$ \\
\hline
\end{tabular}

Note.-SDs are given in parentheses. $N=206$ for mail responses and 345 for phone responses.

* Fixed variables retain the same value in each period or are available for only one period. Changing variables were collected as event histories and are coded "0" before the event occurs and "1" after the event occurs.

$\dagger$ Four outliers were top-coded at 15 complaints. The internalization ratio is constructed from the original, rather than the top-coded, complaint data. Two organizations that processed complaints for other agencies were dropped from the analyses. 
TABLE 3

Maximum Likelihood Tobit Regression of External Complaints

\begin{tabular}{|c|c|c|c|c|}
\hline Variable & Coefficient & $T$-ratio & $\begin{array}{c}\Delta \text { in } \\
\text { Number }\end{array}$ & $\begin{array}{c}\Delta \text { in } \\
\text { Probability } \\
(\%)\end{array}$ \\
\hline \multicolumn{5}{|l|}{ Model 1: } \\
\hline 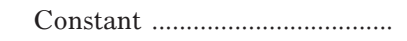 & $-4.57 * * *$ & -3.75 & & \\
\hline EEO procedure …........................ & .62 & .63 & .19 & 5 \\
\hline 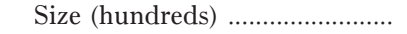 & $.17 * * *$ & 6.85 & .05 & 1 \\
\hline 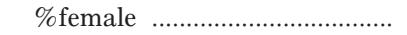 & 1.04 & .59 & .32 & 8 \\
\hline$\%$ minority & $3.72 *$ & 1.68 & 1.13 & 29 \\
\hline 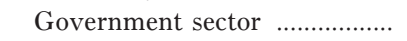 & .15 & .12 & .05 & 1 \\
\hline College sector & -.25 & -.19 & -.08 & -2 \\
\hline 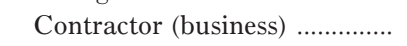 & $1.92 *$ & 1.82 & .58 & 15 \\
\hline 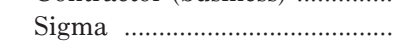 & $4.87 * * *$ & 11.40 & & \\
\hline 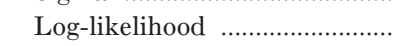 & \multicolumn{2}{|c|}{-294.66} & & \\
\hline$N$ & \multicolumn{2}{|c|}{205} & & \\
\hline \multicolumn{5}{|l|}{ Model 2: } \\
\hline 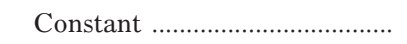 & $-6.21 * * *$ & -4.27 & & \\
\hline 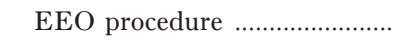 & -.44 & -.46 & -.13 & 4 \\
\hline 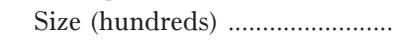 & $.12 * * *$ & 4.95 & .04 & 1 \\
\hline 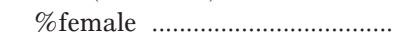 & 1.19 & .71 & .36 & 10 \\
\hline 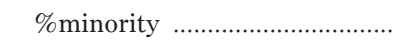 & 2.64 & 1.24 & .80 & 22 \\
\hline 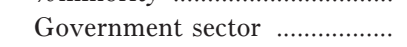 & -1.05 & -.83 & -.32 & -9 \\
\hline College sector & -1.50 & -1.19 & -.46 & -13 \\
\hline Contractor (business) ................... & .88 & .87 & .27 & 7 \\
\hline EEO office & $3.10 * * *$ & 2.86 & .94 & 26 \\
\hline 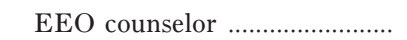 & $2.40 * *$ & 2.03 & .73 & 10 \\
\hline 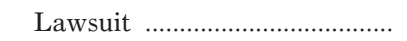 & $2.29^{* *}$ & 2.48 & .69 & 18 \\
\hline 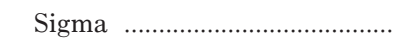 & $4.51 * * *$ & 11.51 & & \\
\hline Log-likelihood ............................... & \multicolumn{2}{|c|}{-284.52} & & \\
\hline$N$ & \multicolumn{2}{|c|}{205} & & \\
\hline
\end{tabular}

$* P<.10$

$* * P<.05$.

*** $P<.01$.

ance procedure. Model 1 shows EEO procedure and organizational and sectoral control variables. In model 2, we add other EEO characteristics that may affect an organization's propensity to elicit complaints.

Table 3 shows that specific EEO grievance procedures have little effect on the volume of complaints to external fair employment agencies. In model 1, the coefficient is close to zero and positive, and in model 2 the coefficient is close to zero and negative. This is the strongest evidence that managers' common beliefs in the buffering capacity of such procedures are probably wrong. Without the additional EEO variables (model 1), 
only organizational size, ${ }^{12}$ the percentage minority, and government contractor status have even marginally statistically significant effects on the volume of external complaints. ${ }^{13}$ Approximately $30 \%$ of the total effect of each independent variable is on increasing or decreasing the number of complaints among organizations that had at least one complaint, and about $70 \%$ of the effect is on increasing or decreasing the probability of experiencing a complaint among organizations that had no complaints. ${ }^{14}$ Among organizations with complaints, a 1,000-worker increase in fulltime employees corresponds to an additional one-half of one complaint; among organizations without complaints, it corresponds to a $10 \%$ higher probability of experiencing a complaint. ${ }^{15} \mathrm{~A} 10 \%$ increase in the minority workforce similarly corresponds to about one-tenth of one complaint among organizations with complaints and raises the probability of experiencing a complaint by about $3 \%$. Businesses with government contracts were about $15 \%$ more likely to have a complaint and experienced about 0.6 more complaints than noncontractor businesses.

Including the additional EEO characteristics in model 2 significantly improves the fit of the model and mediates the effects of the percentage of minority employees and the contractor status. As expected, organizations with EEO offices and EEO counselors have a greater propensity to elicit complaints since offices tend to call attention to civil rights and staff

${ }^{12}$ We also estimated a series of models predicting the ratio of complaints to organizational size. Our substantive findings are robust under this specification: EEO procedures again fail to significantly alter the level of complaints to external agencies.

${ }^{13}$ Note that the sector variables (government and college) are not generally statistically significant in these analyses. These are key variables in institutional analyses and are generally found to be statistically significant in modeling diffusion processes (e.g., Edelman 1990, 1992). Their lack of significance here suggests that vulnerability to the institutional environment does not directly drive the complaint process.

${ }^{14}$ We obtain these numbers using Roncek's (1992) equation 4a for organizations with at least one external complaint, $B_{1} \times\left[1-(z \times f(z) / F(z))-f(z)^{2} / F(z)^{2}\right]$, where $B_{1}$ is the Tobit coefficient for a particular independent variable, $f(z)$ is the unit normal density or the value of the derivative of the normal curve at $z, F(z)$ is the cumulative normal distribution function for the proportion of cases with at least one complaint, $\mathrm{z}$ is the $\mathrm{z}$-score associated with the area under the normal curve, and sigma is the standard deviation of the error term in the estimated equation. For model 1 of table $3, \mathrm{~B}_{1} \times\{1-(-.3042) .3807 / .3805\}-\left(.3807^{2} / .3805^{2}\right)=\mathrm{B}_{1} \times .3033$. For organizations not experiencing complaints, the change in the cumulative probability of having a complaint is $B_{1} \times f(z) /$ sigma or $B_{1} \times .0782$ (from Roncek 1992, p. 504, eq. 4b).

${ }^{15} \mathrm{We}$ obtain these interpretations for organizations with complaints and without as follows:

for size, $\mathrm{B}=.17 \times .3033=.05$ per hundred (or $.5 /$ thousand) and $.17 \times .0782=.013 /$ hundred or $13 \% /$ thousand; for percentage minority, $\mathrm{B}=3.72 \times .3033=1.13(\times .1)$ $=.11$ and $3.72 \times .0782=.29(\times .1)=3 \%$ per $10 \%$ increase; for contractor, $\mathrm{B}=1.92$ $\times .3033=.58$ and $1.92 \times .0782=.15$. 
may encourage employees to pursue those rights (Edelman et al. 1991). Having an EEO office increases the expected number of complaints by almost one full complaint $(3.1 \times .3033=.94)$ and raises the probability of experiencing any complaint by $26 \%(3.1 \times .0844=.26)$. Having experienced a previous discrimination-related lawsuit is also a strong predictor of the volume of external complaints, increasing the expected number of complaints by 0.7 and raising the probability of experiencing any complaint by $18 \%$. As discussed above, this probably represents a combination of the effect of complaints motivated by discrimination and the heightened rights awareness that may accompany lawsuits.

A number of factors, found to have no statistically significant effect, are omitted from the estimated models shown in table 3. Other than organizational size and contractor status, which have the expected positive effects on external complaints, ${ }^{16}$ organizational characteristics (age, professionalization, and the presence of a union) have small nonsignificant effects. Although preliminary analyses had shown the number of lawyers employed by the organization to have a positive effect on the number of external complaints, we omit this factor because we are unsure of the temporal ordering of attorneys and complaints. Variables representing region, core/periphery, and manufacturing/service are not statistically significant.

In addition to their apparent inability to buffer organizations from $e x$ ternal complaints, table 4 shows that EEO grievance procedures may increase the volume of internal discrimination complaints. The effect of EEO grievance procedures on internal complaints is statistically significant in model 1, but this effect is mediated by EEO offices, EEO counselors, and lawsuits in model 2. In model 1, having an EEO procedure increases the expected number of complaints by more than one-half of one complaint $(2.15 \times .2976=.64)$ and raises the probability of experiencing a complaint by $18 \%(2.15 \times .0821=.177)$. EEO counselors are especially likely to channel employees toward internal forums, increasing the expected number of complaints in model 2 by 1.4 and raising the probability of experiencing a complaint by $42 \%$. Since EEO counselors often handle discrimination complaints and problems, they are likely to be vested in the internal resolution of complaints (Edelman et al. 1993). As with external complaints, there is a marginally higher volume of internal complaints in

\footnotetext{
${ }^{16}$ In organizational analysis, it is common to use the log of size rather than raw size because it is generally the case that an increase in the size of a relatively small organization will have a greater effect on organizational structure than an increase in the size of larger organization. In predicting the number of complaints, however, we do not log size since every additional employee would appear to add an equal chance of a discrimination complaint. We do represent the size variable in hundreds of employees, however, so that the coefficients provide more information.
} 
TABLE 4

Maximum Likelihood Tobit Regression of Internal Complaints

\begin{tabular}{|c|c|c|c|c|}
\hline Variable & Coefficient & $t$-ratio & $\begin{array}{c}\Delta \text { in } \\
\text { Number }\end{array}$ & $\begin{array}{c}\Delta \text { in } \\
\text { Probability } \\
(\%)\end{array}$ \\
\hline \multicolumn{5}{|l|}{ Model 1: } \\
\hline Constant ................................... & $-4.66^{* * * *}$ & -4.03 & & \\
\hline EEO procedure & $2.15 * *$ & 2.35 & .64 & 18 \\
\hline Size (hundreds) ....................... & $.19 * * *$ & 8.35 & .06 & 2 \\
\hline 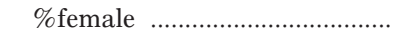 & -.69 & -.41 & -.21 & -6 \\
\hline 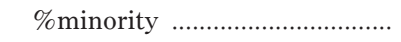 & $5.55 * * *$ & 2.65 & 1.65 & 46 \\
\hline Government sector ................. & .82 & .69 & .24 & 7 \\
\hline 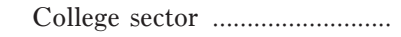 & $1.95 *$ & 1.68 & .58 & 16 \\
\hline Contractor (business) .............. & 1.07 & 1.05 & .32 & 9 \\
\hline Sigma & $4.60 * * *$ & 11.09 & & \\
\hline Log-likelihood .......................... & \multicolumn{2}{|c|}{-284.99} & & \\
\hline$N$ & \multicolumn{2}{|c|}{205} & & \\
\hline \multicolumn{5}{|l|}{ Model 2: } \\
\hline 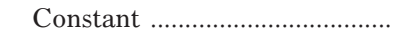 & $-8.15 * * *$ & -4.88 & & \\
\hline EEO procedure ........................... & 1.28 & 1.47 & .38 & 12 \\
\hline 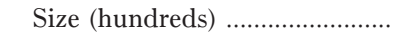 & $.15 * * *$ & 6.57 & .05 & 1 \\
\hline 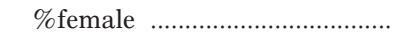 & 1.16 & 1.03 & .35 & 10 \\
\hline 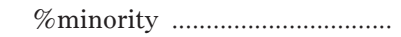 & $4.88 * *$ & 2.34 & 1.45 & 44 \\
\hline Government sector ................... & .07 & .05 & .02 & 1 \\
\hline 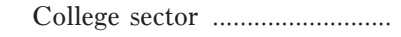 & 1.16 & 1.03 & .35 & 10 \\
\hline Contractor (business) ............. & .18 & .19 & .06 & 2 \\
\hline 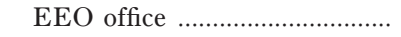 & $2.01 * *$ & 2.00 & .60 & 18 \\
\hline EEO counselor ........................... & $4.69 * * *$ & 3.38 & 1.40 & 42 \\
\hline 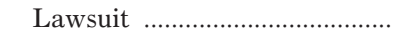 & $1.64 *$ & 1.88 & .49 & 15 \\
\hline Sigma & $4.25 * * *$ & 11.24 & & \\
\hline Log-likelihood ....................... & \multicolumn{2}{|c|}{-272.22} & & \\
\hline$N$ & \multicolumn{2}{|c|}{205} & & \\
\hline
\end{tabular}

\footnotetext{
$* P<.10$

$* * P<.05$.

*** $P<.01$.
}

organizations that have experienced a prior discrimination-related lawsuit, suggesting effects of either greater discrimination or greater rights awareness. As in the analysis of external complaints, only size and the percentage of minority employees had a statistically significant effect among the other organization-level or sector-level variables.

The results presented so far, then, suggest that EEO grievance procedures have relatively small effects on the volume of external and internal complaints. However, their presence indirectly affects the volume of internal complaints because EEO offices and EEO counselors appear to en- 
courage their use. This raises the possibility that, controlling for the volume of total EEO complaints, specific EEO grievance procedures may be associated with greater internalization of these complaints. By modeling the internalization ratio, that is, the ratio of internal complaints to total (internal and external) complaints, we determine the effect of EEO grievance procedures and other organizational and environmental factors on the internalization of complaints.

Because organizations must have experienced at least one complaint to calculate the internalization ratio, there is a possibility of selectivity bias in estimating the ratio; factors that affect whether organizations experience any complaints are likely to be associated with internalization. To control for this possibility, we use Heckman's (1976) selectivity approach to model jointly the process generating any complaint and the process generating the internalization of complaints. ${ }^{17}$ This is a generalization of the Tobit model, in which $\mathrm{Y} * 2_{\mathrm{i}}$, representing whether any complaints are filed, affects whether $\mathrm{Y} 1_{\mathrm{i}}$ (the internalization ratio) is observed (see Winship and Mare 1992). Thus, this model takes the form:

1. $\mathrm{Y} * 1_{\mathrm{i}}=\mathrm{X}_{\mathrm{i}} \mathrm{B}+\mathrm{e}_{\mathrm{i}}$,

2. $\mathrm{Y} 1_{\mathrm{i}}=\mathrm{Y} * 1_{\mathrm{i}}$ if $\mathrm{Y} * 2_{\mathrm{i}}>0$,

3. $\mathrm{Y} 1_{\mathrm{i}}=0$ if $\mathrm{Y} * 2_{\mathrm{i}} \leq 0$.

Table 5 shows the selection model predicting whether organizations will have at least one complaint. This equation produces a coefficient, lambda, that we use to statistically adjust the internalization ratio equation for selectivity. Heckman's method is most appropriate when there is a determinant of the selection equation that can be excluded from the substantive equation. One such exclusion is unionization: unionized organizations are more likely than nonunionized organizations to experience complaints, but there is less reason to expect unionization to affect internalization. ${ }^{18}$ Table 5 is also substantively relevant, showing that specific

${ }^{17}$ For this part of the article, we would prefer to have information at the level of the individual complaint rather than at the organizational level of analysis. Although we can recover the proportion of internal to total complaints for each organization, data on the type and fate of individual complaints would speak more directly to the efficacy of EEO grievance procedures and processes of internalization. In addition to the internalization ratio selection model discussed below, we also estimated nonratio models predicting internal and external complaints using total complaints as a regressor. We also specified ratio models with 1/total complaints (Gibbs and Firebaugh 1985, p. 717) as a predictor and censored regression models with an upper limit of one and a lower limit of zero. In each case, the substantive results with respect to EEO procedures and counselors parallel those presented in table 6 .

${ }^{18}$ Since no exclusionary restriction is ideal, we also specified models omitting factors such as organizational size, region, and industry from the substantive equation. When 
TABLE 5

Selection Equation Predicting Any Complaint

\begin{tabular}{|c|c|c|c|c|}
\hline \multirow[b]{2}{*}{ VARIABLE } & \multicolumn{2}{|c|}{ Model 1} & \multicolumn{2}{|c|}{ MODEL 2} \\
\hline & Coefficient & $t$-ratio & Coefficient & $t$-ratio \\
\hline 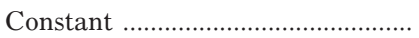 & $-.93 * * *$ & -3.44 & $-1.50 * * *$ & -4.38 \\
\hline EEO procedure .......................... & $.66 * * *$ & 2.67 & $.44 *$ & 1.65 \\
\hline 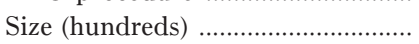 & $.06 * * *$ & 3.87 & $.04 * * *$ & 2.69 \\
\hline 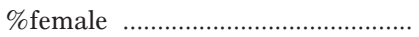 & .09 & .23 & .06 & .14 \\
\hline 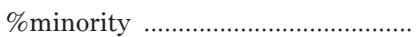 & .65 & 1.29 & .50 & .95 \\
\hline Government sector $\ldots \ldots \ldots \ldots \ldots \ldots \ldots \ldots$ & -.33 & -1.10 & -.51 & -1.53 \\
\hline 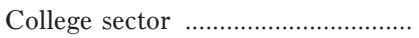 & .23 & .29 & .07 & .23 \\
\hline 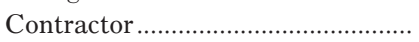 & $.78 * * *$ & 2.98 & $.66 * *$ & 2.42 \\
\hline 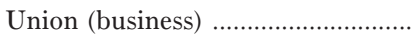 & .27 & 1.35 & .29 & 1.38 \\
\hline 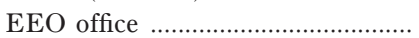 & & & .50 & 1.56 \\
\hline 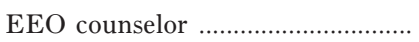 & & & $.83 * * *$ & 3.08 \\
\hline 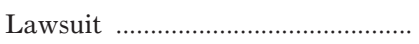 & & & .28 & 1.39 \\
\hline Log-likelihood .............................. & \multicolumn{2}{|c|}{-112.66} & \multicolumn{2}{|c|}{-104.87} \\
\hline$N \quad \ldots \ldots+\cdots \cdots$ & \multicolumn{2}{|c|}{205} & \multicolumn{2}{|c|}{205} \\
\hline
\end{tabular}

$* P<.10$.

** $P<.05$.

$* * * P<.01$.

EEO grievance procedures have a statistically significant effect on the likelihood that organizations will experience at least one discrimination complaint. This is notable because many organizations that do not have special EEO grievance procedures already have general grievance procedures in place that could be used for discrimination complaints. Federal contractors and organizations with EEO counselors are also more likely to have at least one complaint. Not surprisingly, size is statistically significant. Table 6 shows models predicting the internalization ratio, adjusted for selectivity bias. EEO grievance procedures have a marginally statistically significant effect on internalization, standardized by overall volume. Colleges, relative to private businesses, are particularly successful at internalizing EEO complaints. EEO counselors also have a strong effect on the internalization ratio. There are several possible interpretations of the effect of special EEO grievance procedures on the internalization ratio. First, if these procedures exert a small negative effect on the volume

these models (which include unionization in both equations) are tested, the coefficient for unionization in the internalization ratio equation is close to zero $(-0.05)$ with $p$ values of approximately 0.5 . Under these specifications, however, the models are less stable and the overall fit is worsened. The zero-order correlation is -0.008 between unionization and internalization and 0.16 between unionization and any complaint. 
TABLE 6

Selection Equation Predicting Internalization Ratio

\begin{tabular}{|c|c|c|c|c|}
\hline \multirow[b]{2}{*}{ VARIABLE } & \multicolumn{2}{|c|}{ Model 1} & \multicolumn{2}{|c|}{ MOdel 2} \\
\hline & Coefficient & $t$-ratio & Coefficient & $t$-ratio \\
\hline Constant . & .28 & 1.10 & -.22 & -.48 \\
\hline EEO procedure ………..................... & $.21 *$ & 1.93 & $.19 *$ & 1.79 \\
\hline 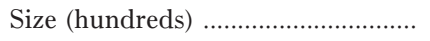 & .004 & 1.04 & .004 & 1.25 \\
\hline 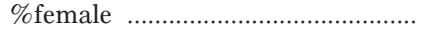 & -.20 & -1.20 & $-.28 *$ & -1.67 \\
\hline 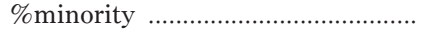 & .18 & .82 & .14 & .62 \\
\hline Government sector & .002 & .02 & -.02 & -.17 \\
\hline College sector & .17 & 1.54 & $.20 *$ & 1.67 \\
\hline 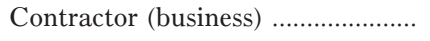 & .06 & .53 & .06 & .53 \\
\hline 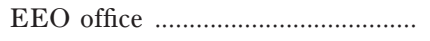 & & & .04 & .35 \\
\hline 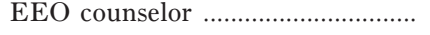 & & & $.52 * *$ & 2.35 \\
\hline 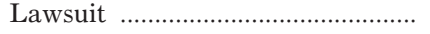 & & & -.02 & -.29 \\
\hline Selection correction …...................... & .21 & 1.00 & .33 & 1.23 \\
\hline 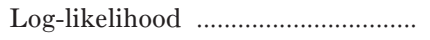 & \multicolumn{2}{|c|}{-28.49} & \multicolumn{2}{|c|}{-23.85} \\
\hline$N$ & \multicolumn{2}{|c|}{ 205, 98} & \multicolumn{2}{|c|}{ 205, 99} \\
\hline$R^{2}$ & \multicolumn{2}{|c|}{.10} & \multicolumn{2}{|c|}{.15} \\
\hline
\end{tabular}

$* P<.10$

** $P<.05$.

*** $P<.01$.

of external complaints and a small positive effect on the volume of internal complaints, the difference could produce a statistically significant effect on the internalization ratio. Second, if EEO offices and counselors drive up the volume of total complaints, special EEO grievance procedures could divert a portion of the excess volume to internal forums. Third, and we think this is the most likely explanation, the presence of an EEO grievance procedure together with the actions of EEO offices and EEO counselors may motivate different types of complaints, which are more likely to be pursued in internal forums. In particular, whereas external forums are most likely to be used for claims involving discrimination in hiring and firing (Donahue and Siegelmann 1991), internal grievance procedures may be more likely to attract claims involving working conditions and, in particular, sexual harassment. The positive (though nonsignificant) value for the selection correction term suggests that organizations experiencing at least one complaint may possess unmeasured characteristics, such as rights consciousness, for example, that are positively related to internalization.

Taken together, the analyses summarized in tables 3-6 show that special EEO grievance procedures generally fail to insulate organizations from the threat of complaints to external fair-employment agencies. Addi- 
tional analyses (not shown) suggest that general grievance procedures also had no insulating effect. Thus, many of the claims of the personnel, legal, and management professions about the rationality of these procedures are largely mythical. The presence of EEO grievance procedures is associated with a greater propensity to elicit internal complaints, although it appears to be EEO offices and EEO counselors, rather than the procedures themselves, that drive the volume (and possibly the nature) of these complaints. Thus, EEO grievance procedures may play an important role in resolving complaints within the firm, but they do not appear to protect organizations from experiencing external complaints or litigation.

\section{THE MYTH OF JUDICIAL DEFERRAL TO GRIEVANCE PROCEDURES}

In this section, we examine the claims of the personnel and legal professions that courts will look favorably upon organizations with grievance procedures. In particular, we examine evidence regarding the two major assertions that we found in the personnel literature: (1) employers with internal grievance procedures in place are less likely to be found in violation of civil rights law because the grievance procedures will serve as evidence of fair treatment; and (2) if an employer has an internal grievance procedure, courts may dismiss an employee's lawsuit for failure to use that grievance procedure.

These arguments had little legal foundation at the time that the personnel literature began to articulate them since virtually all discrimination claims were at that time decided under a vicarious liability standard. Under that standard, employers are held responsible for the wrongful acts of their employees regardless of whether they knew about the wrong doing. Thus, neither a policy against discrimination nor a grievance procedure would help an employer escape liability. Not surprisingly, few cases prior to the mid-1980s even discussed the relevance of grievance procedures.

In contrast to the assertions of articles such as those quoted earlier, the vicarious liability standard applied to sexual (and also racial) harassment cases as well as to discrimination cases through the mid-1980s. Since the 1964 Civil Rights Act did not explicitly prohibit sexual harassment, courts had to decide whether it constituted sexual discrimination under the law. Prior to 1986, courts were most responsive to allegations of quid pro quo sexual harassment, in which supervisors demanded sexual favors as a condition of employment or retaliated for denial of those favors. The judicial position on the role of grievance procedures under the vicarious liability standard is apparent, for example, in the federal court of appeals case of 
Miller v. Bank of America (600 F.2d 211 [1979]). ${ }^{19}$ In Miller v. Bank of America, the plaintiff sued because she was fired after refusing her supervisor's demand for sexual favors from a "black chick." Bank of America argued that it should not be liable because it had an established policy against harassment and had afforded Ms. Miller an opportunity for redress through its internal grievance procedure. Citing similar cases from four other federal appellate circuits, the court held that, under the doctrine of respondeat superior (a type of vicarious liability), employers are liable for the acts of their agents (here, the supervisor) regardless of any policies against those acts and regardless of the employer's knowledge of those acts. It held, moreover, that Title VII does not require employees to use internal grievance procedures before filing formal legal claims. ${ }^{20}$

${ }^{19}$ There was some variation in the courts on the issue of vicarious liability at this time. One federal district court held that an employer could not be held liable for the sexual harassment of an employee by a supervisor unless there was an explicit company policy condoning the harassment (Corne v. Bausch \& Lomb, 390 F.Supp. 161 [1975]). Another specifically rejected the logic in the Corne case and held that sexual harassment by a supervisor was a violation of Title VII as a matter of law because it created an artificial barrier to employment that burdened one gender but not the other (Williams v. Saxbe, 413 F.Supp. 654 [1976]). A third case treated the supervisor as an agent of the employer, which meant that a policy or practice of a supervisor constituted a policy or practice of the company under the doctrine of respondeat superior (Munford v. Barnes, 441 F.Supp. 459 [1977]). In Munford, the court arguably raised the possibility that an employer could take some affirmative action that would insulate it from liability by suggesting that the employer was responsible because it had not investigated the harassment even after it was given notice. But since then, courts generally have a vicarious liability theory in quid pro quo cases, which means that the employer is responsible whether or not the employer knew, should have known, or approved of the supervisor's actions (e.g., Anderson v. Methodist Evangelical Hospital, Inc., 464 F.2d 723, 725 [CA6 1972]).

${ }^{20}$ Interestingly, the Linenberger and Keaveny article (1981) mentioned earlier cites the Miller case in suggesting that grievance procedures would be valuable in litigation. This may be based on a comment at the end of the case suggesting that the holding will not put an undue burden on employers because, if the EEOC determines that there is reasonable cause to believe that discrimination has occurred, it must allow for conciliation. The court suggests that "an employer whose internal procedures would have redressed the alleged discrimination can avoid litigation by employing those procedures to remedy the discrimination upon receiving notice of the complaint or during the conciliation period" (Miller v. Bank of America, 214). This does not suggest, however, that if the case does eventually go to court, the court will be impressed by the grievance procedure. The Linenberger and Keaveny article also refers to the EEOC guidelines in making its claim. Here, ambiguity in the guidelines may have contributed to the article's claims. The first guidelines on sexual harassment, issued in 1980, state explicitly that employers are vicariously liable for the acts of their agents. "Applying general Title VII principles, an employer . . . is responsible for its acts and those of its agents and supervisory employees with respect to sexual harassment regardless of whether the specific acts complained of were authorized or even forbidden by the employer and regardless of whether the employer knew or 
A new theory of sexual harassment-the hostile work environment theory - began to evolve in the early 1980s (Hipp 1988). Under this theory, an employee may sue because coworkers' harassing acts make the workplace intolerable for the plaintiff. Because this new type of sexual harassment often involves harassment by coworkers rather than by supervisors, the issue of agency is more problematic and thus the courts look for signs of ratification of the harassment by the employer rather than simply holding the employer vicariously liable.

The hostile work environment theory was formally recognized by the United States Supreme Court in the 1986 case of Meritor Savings Bank v. Vinson (106 Sup. Ct. 2399 [1986]). The plaintiff, Michelle Vinson, alleged that her supervisor, Sidney Taylor, made repeated demands for sexual relations, fondled her at work, and raped her on several occasions. Vinson testified that she did not report Taylor's behavior or use the company's grievance procedure because of her fear of Taylor. Meritor Savings Bank argued that because it did not know of any sexual misconduct by Taylor, it could not be held responsible. In its review of the case, the court of appeals used a vicarious liability standard and held that, irrespective of the availability of the grievance procedure, the bank was liable for Taylor's conduct. The Supreme Court then reversed the court of appeals, recognizing the hostile environment cause of action and replacing the vicarious liability standard with a standard of direct liability in which only employers who knew or should have known about the discriminatory acts

should have known of their occurrence" 29 C.F.R. \$1604.11(c). However, the next section is ambiguous and seemingly contradictory and suggests that an employer's subsequent actions may sometimes affect liability. "With respect to persons other than those mentioned in paragraph (c) of this section, an employer is responsible for acts of sexual harassment in the workplace where the employer, or its agents or supervisory employees, knows or should have known of the conduct. An employer may rebut apparent liability for such acts by showing that it took immediate and appropriate corrective action" 29 C.F.R. $\$ 1604.11(d)$. One year later, paragraph (d) was revised to state "With respect to conduct between fellow employees." Thus, vicarious liability would seem to apply only to supervisors and not to fellow employees. Finally, paragraph (e) raises the issue of grievance resolution, although it suggests that employers should inform employees of their right to complain to the EEOC and does not mention internal complaints. "Prevention is the best tool for the elimination of sexual harassment. An employer should take all steps necessary to prevent sexual harassment from occurring, such as affirmatively raising the subject, expressing strong disapproval, developing appropriate sanctions, informing employees of their right to raise and how to raise the issue of harassment under Title VII, and developing methods to sensitize all concerned" 29 C.F.R. \$1604.11(e). The suggestion in the EEOC guidelines that agency principles might sometimes apply, together with paragraph (e), which raises the issue of employers' responsibilities, may have led Linenberger and Keaveny (1981) and others to recommend internal grievance procedures. But nothing in the guidelines, or any cases we were able to find, specifically suggests that employers may avoid liability by creating internal grievance procedures. 
of their agents are liable. With the adoption of the direct liability standard, the earlier claims of personnel professionals suddenly gained validity since employers could argue that their grievance procedures constituted evidence that they sought to learn about and correct their agents' misdeeds. Though the court in the Meritor case held that the grievance procedure in question was inadequate to insulate the employer from liability (because it required the victim to complain directly to her alleged harasser), it noted that in a future case, a better grievance procedure might provide such insulation. "The bank's grievance procedure apparently required an employee to complain first to her supervisor, in this case Taylor. Since Taylor was the alleged perpetrator, it is not altogether surprising that respondent failed to invoke the procedure and report her grievance to him. Petitioner's contention that respondent's failure should insulate it from liability might be substantially stronger if its procedures were better calculated to encourage victims of harassment to come forward" (Meritor Savings Bank v. Vinson, 72-73).

Thus, although the court found the grievance procedure in question in the Meritor case inadequate, it reinforced the personnel professions' claims that grievance procedures may insulate employers from liability. Almost immediately after that case was decided, a federal circuit court of appeals adopted a similar standard in racial harassment cases (Hunter $v$. Allis-Chalmers, 797 F.2d 1417 [1986]). Racial harassment cases are quite similar to hostile work environment sexual harassment cases in that they involve acts that may make the workplace intolerable for minorities but do not necessarily involve direct threats to one's economic welfare.

Further, a recent Supreme Court decision-Faragher v. City of Boca Raton (118 Sup. Ct. 1115 [1998])—both reinforces the decision in Meritor Savings Bank v. Vinson on hostile environment sexual harassment and gives credence to the personnel profession's claim that employers may avoid liability where they have an internal grievance procedure in place and an employee fails to use it. ${ }^{21}$ The court held, "While proof that an employee failed to fulfill the ... obligation of reasonable care to avoid

\footnotetext{
${ }^{21}$ A concurring opinion in the Meritor case also suggested that an employee's failure to use an internal complaint procedure might render a court reluctant to find that the employee was constructively discharged, since the employee had waived an opportunity to redress her grievance. The concurring opinion, written by Justice Marshall and joined by Justices Brennan, Blackmun, and Stevens, would have retained the vicarious liability standard but nonetheless suggests that an employer's attempts to redress grievances may be relevant to the issue of remedies. In this regard, the opinion states that "where a complainant without good reason bypassed an internal complaint procedure she knew to be effective, a court may be reluctant to find constructive termination and thus to award reinstatement or backpay" (Meritor Savings Bank v. Vinson, 2399, 2411).
} 
harm is not limited to showing an unreasonable failure to use any complaint procedure provided by the employer, a demonstration of such failure will normally suffice to satisfy the employer's burden [of proof]."

The law on hostile environment sexual harassment cases since 1986 (and to an even greater extent in 1998), then, very much fits with the claims made by the personnel profession in the late 1970s and early 1980s. But the law on virtually all other types of discrimination claims remains one of vicarious liability: an employer is responsible for the acts of its agents irrespective of an internal grievance procedure. Even the law on hostile environment sexual harassment claims, moreover, developed after the personnel professions' claims regarding the value of internal grievance procedures, as they were presented in the late 1970s and early 1980s. It would appear, then, that judicial recognition of grievance procedures did not motivate personnel professionals' claims and organizations' creation of grievance procedures but rather that the courts were following institutionalized organizational practices. The only other explanation, which we examine below, would be that the court in the Meritor case was recognizing a trend that had become well established in the lower courts. This does not, however, appear to be the case.

To determine when the law began to recognize grievance procedures as a source of protection for employers and the extent to which internal grievance procedures insulate employers from legal liability, we conducted a content analysis of all available federal Title VII cases involving sexual or racial discrimination or harassment in which employers discussed "the grievance procedure defense"; that is, they asserted that they should not be held liable for discrimination because they had a grievance procedure in place. ${ }^{22}$

We searched the Westlaw federal case database for all cases from 1964 through 1997, which alleged sexual or racial discrimination or harassment under Title VII of the 1964 Civil Rights Act and also addressed the relevance of grievance procedures. ${ }^{23}$ The search found a total of 477 cases, none prior to 1970. Of these, 161 cases were excluded for one or more of the following reasons: they were not Title VII cases (or the part of the case addressing grievance procedures did not involve Title VII); they did not in fact involve the grievance procedure defense; they did not involve racial or sexual discrimination or harassment; or they were duplicate cases. We also eliminated 177 cases that involved union grievance proce-

\footnotetext{
${ }^{22}$ In most cases, the grievance procedure defense is asserted in combination with other defenses against liability.

${ }^{23}$ The search request, which was conducted for each year within the period 1964-98 within the federal case database, was "Title VII" \& race racial sex! /P "grievance procedure!".
} 
dures, which tend to be decided by reference to collective bargaining agreements and therefore cloud the issue of judicial deferral to organizational grievance procedures. This left us with 129 cases.

Westlaw is one of the two major on-line databases that are used by the legal profession to discover precedent (the other is Lexis). ${ }^{24}$ Since attorneys tend to rely heavily on on-line case reporters, these databases are the de facto case law that influences judges, lawyers, and employers. ${ }^{25}$ Because we only searched for cases that discussed grievance procedures, the data do not speak to the question of what proportion of all discrimination cases involve an employer's claim that the grievance procedure should provide insulation. The cases do tell us, however, when the grievance procedure defense first arose and when it has been successful in insulating employers from Title VII civil rights complaints.

The variables we coded for the case analysis are shown in table 7 . The dependent variable of interest is whether a court deferred to an organization's internal grievance procedure. We coded deferral in two different ways. We coded a case as involving a "theoretical deferral" where, in the abstract (i.e., not considering the merits of the grievance procedure in that particular case), the court stated that it would base its decision at least in part on whether the organization had an internal grievance procedure. ${ }^{26}$

${ }^{24}$ When a court renders an opinion, it may order that the opinion be published in official case reporters; it may make the opinion generally available for public distribution but with the limitation that it is to be considered legally "unpublished" and thus not cited as precedent; or it may simply file the opinion with the general public records available at the court, in which case it generally does not appear in the official reporters or on-line databases. (On rare occasions an opinion may be "sealed" and not available to the public at all.) The Westlaw federal database is based on extensive efforts to include all "published" and (legally) "unpublished" cases from federal courts. Since in some cases a court allows the (legally) unpublished cases to appear on-line and not in the reporters, the Westlaw database is more comprehensive than the reporters. In addition, although the Westlaw database does not generally include cases where the court simply files the opinion, occasionally even those cases will be included if a request is made and the court approves it.

${ }^{25}$ To the extent that published cases are not representative of all cases, they tend to overrepresent novel decisions and underrepresent established law. This might mean that cases deferring to grievance procedures are somewhat overrepresented. On the other hand, all cases involving hostile work environment claims in general, and grievance procedures in particular, address novel issues and are therefore likely to be included.

${ }^{26}$ The coding instruction for theoretical deferral was: "In the abstract, the court would be willing to be influenced by whether the organization has an internal grievance procedure. This does not mean that the court would base its decision entirely on the presence of internal grievance; rather it simply means that the internal grievance has some degree of influence. Cases where the court says that the grievance procedure in this case is inadequate (perhaps due to lack of notice or the complainant having to complain to her supervisor) may still be coded as theoretical defers if the court would have deferred without those deficiencies in the grievance procedure." 
TABLE 7

Case Analysis: Variables, Descriptive Statistics, and Variable Definitions

\begin{tabular}{|c|c|c|c|}
\hline & Mean & SD & Description \\
\hline Theoretical defer .............. & .87 & .340 & $\begin{array}{l}\text { "1" if court would consider deferring to an } \\
\text { organization's grievance procedure, } \\
\text { "0" if other }\end{array}$ \\
\hline Actual defer ...................... & .36 & .481 & $\begin{array}{l}\text { " } 1 \text { " if court deferred to an organization's } \\
\text { grievance procedure, "0" if other }\end{array}$ \\
\hline Theoretical quality ........ & .81 & .400 & $\begin{array}{l}\text { "1" if the court held that the quality of an } \\
\text { organization's grievance procedure } \\
\text { ought to affect the court's decision to } \\
\text { defer, " } 0 \text { " if other }\end{array}$ \\
\hline Actual quality ................... & .60 & .491 & $\begin{array}{l}\text { " } 1 \text { " if the court's decision with respect to } \\
\text { deferral depended in part on the qual- } \\
\text { ity of the organization's grievance pro- } \\
\text { cedure, " } 0 \text { " if other }\end{array}$ \\
\hline Direct liability .................. & 481 & .502 & $\begin{array}{l}\text { "1" if case alleges either race harassment, } \\
\text { or hostile work environment-only sex } \\
\text { harassment, "0" if other }\end{array}$ \\
\hline Meritor cited …................. & .29 & .458 & $\begin{array}{l}\text { " } 1 \text { " if Meritor cited as precedent in the } \\
\text { opinion, "0" if other }\end{array}$ \\
\hline Year ........................ & 92.2 & 5.151 & Year of court decision \\
\hline
\end{tabular}

NotE. $-N=129$.

We coded a case as involving an "actual deferral" where the court ruled in favor of the employer, in part based on the presence of an internal grievance procedure. ${ }^{27}$ All cases involving actual deferrals must also involve theoretical deferrals, but the reverse is not true. The Meritor case, for example, involves a theoretical deferral but not an actual deferral since the court said that the grievance procedure in that case was deficient but that a better grievance procedure might have insulated the employer from liability (Meritor Savings Bank v. Vinson, 72-73).

The independent variables we use in the analyses include the year of the decision, whether the case was in a class where the direct liability standard is generally used (i.e., racial harassment and hostile work environment sexual harassment cases), whether the Meritor decision was ex-

\footnotetext{
${ }^{27}$ The coding instruction for actual deferral was: The court ruled in favor of the employer, in part based on the presence of a grievance procedure. This does not mean that the court based its decision entirely on the presence of internal grievance; rather it simply means that the internal grievance had some degree of influence. It includes cases where the court was influenced by the complainant's failure to use a grievance procedure.
} 
TABLE 8

Cases Discussing the Grievance Procedure Defense

\begin{tabular}{|c|c|c|c|c|c|c|c|c|}
\hline \multirow{2}{*}{$\frac{\text { Period }}{\text { No theoretical defer } \ldots \ldots \ldots \ldots . . .}$} & \multicolumn{2}{|c|}{$\begin{array}{c}\text { Total } \\
(\%)\end{array}$} & \multicolumn{2}{|c|}{$\begin{array}{c}1974-79 \\
(\%)\end{array}$} & \multicolumn{2}{|c|}{$\begin{array}{c}\text { 1980-86 } \\
\text { (before } \\
\text { Meritor)* } \\
(\%)\end{array}$} & \multicolumn{2}{|c|}{$\begin{array}{c}1986-97 \\
\text { (after } \\
\text { Meritor)* } \\
(\%)\end{array}$} \\
\hline & 17 & (13) & 3 & (75) & & (44) & 10 & (9) \\
\hline Theoretical defer ...................... & 112 & (87) & 1 & (25) & 5 & (56) & 106 & (91) \\
\hline No actual defer ........................ & 83 & (64) & 4 & $(100)$ & & (56) & 74 & (64) \\
\hline 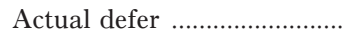 & 46 & (36) & 0 & (0) & 4 & (44) & 42 & (36) \\
\hline Total cases ……...................... & 129 & & 4 & & 9 & & 116 & \\
\hline
\end{tabular}

* Three pre-Meritor 1986 cases are included in the second period. Meritor and one post-Meritor 1986 case are included in the third period.

plicitly cited as precedent, and two variables measuring the court's stance toward the quality of the grievance procedure. The "theoretical quality" variable measures whether the court mentions in its decision that the grievance procedure should provide employees with an adequate and fair means of complaining. The "actual quality" variable means that the court based its decision in part on the quality (or lack thereof) of the grievance procedure in that particular case.

The 129 cases in which employers discussed the grievance procedure defense ranged over the period 1974-97. Our analysis indicates that $\mathrm{Mer}$ itor Savings Bank v. Vinson has legitimated the grievance procedure defense. Since that case, many more employers raise the grievance procedure defense, and courts are far more predisposed to listen. As shown in table 8 , the Westlaw federal database includes only 13 employment cases prior to Meritor in which the grievance procedure defense was even raised. Of those cases, there were six theoretical deferrals, four of which were also actual deferrals. All of the actual deferrals prior to the Meritor case were decided between 1980 and 1986. Although it is possible that these six cases were responsible for the claims of the personnel profession during the 1980 s, it is unlikely since all were district court cases, which receive little publicity. ${ }^{28}$ None of the six cases were cited in the personnel literature. Further, two of the six were not decided until 1986, although prior to Meritor.

Table 8 shows that, in contrast to the very small number of cases (13)

${ }^{28}$ One of those cases was the district court case that eventually led to the Supreme Court decision in Meritor (Vinson v. Taylor, 1980 Westlaw 100). The only case prior to 1980 was Munford v. James T. Barnes, 441 F.Supp. 459, which was decided in 1977. 
addressing the grievance procedure defense prior to Meritor, there are 116 cases after Meritor that raise the grievance procedure defense. Nearly all of the post-Meritor cases (106, or 91\%) involve theoretical deferrals. ${ }^{29}$ Of those 106 cases, $42(36 \%)$ involved actual deferrals. The high percentage of post-Meritor theoretical deferrals is particularly striking. The high percentage of post-Meritor deferrals, in part, reflects the increase in the number of hostile work environment sexual harassment cases, in which courts are the most likely to use the direct liability standard and therefore recognize the possibility of deferring to internal grievance procedures. Significantly, the rise in the number of hostile environment cases and judicial deferrals is itself endogenous. As plaintiffs and their lawyers bring actions in evolving areas of the law, employers and their lawyers frame their arguments so that courts will be likely to defer to their internal grievance procedures. These numbers strongly suggest that Meritor has encouraged employers and their lawyers to raise the grievance procedure defense.

Figure 2 complements table 8 by showing continuous-time trends for cases involving actual and theoretical deferrals in comparison to cases not involving a deferral. The figure shows that the number of cases addressing the grievance procedure defense is quite low until 1986 and then begins to rise. Theoretical deferrals begin to take off in the late 1980s, after the Meritor decision, and actual deferrals begin rising about four years later, reflecting the gradual institutionalization of the grievance procedure defense.

We next conducted a logistic regression analysis to examine how the year of the case, the type of case, judicial attention to grievance procedures, and the Meritor precedent combined to affect the likelihood of deferral. Because nearly all the cases after Meritor involve theoretical deferrals, and because the actual deferral variable provides a better measure

\footnotetext{
${ }^{29}$ The following case provides an example of theoretical and actual judicial deferral to organizational grievance procedures. In a 1992 federal district court case, Giordano v. Paterson College of New Jersey (804 F.Supp. 637 [1992]), a female campus police officer had filed both formal and informal complaints of sexual harassment naming three male coworkers. The affirmative action officer found "inappropriate behavior" but no sexual harassment. The officer recommended that all department employees attend a sexual harassment workshop, but the lawsuit alleges that the harassment continued, eventually causing the employee to quit her job. She filed suit for sexual harassment based on a hostile environment. The court held that "the College promptly and adequately responded to Giordano's complaints. As a result the College cannot be liable for sexual harassment based on a hostile environment claim" (Giordano v. Paterson College of New Jersey, 644). Thus, the court granted the employer's motion for summary judgement, essentially deciding that because the employer had a grievance procedure, the employee filed a grievance, and the employer took some action, the employer won as a matter of law - the case should not go to a jury for determination of whether the response of the college was adequate.
} 


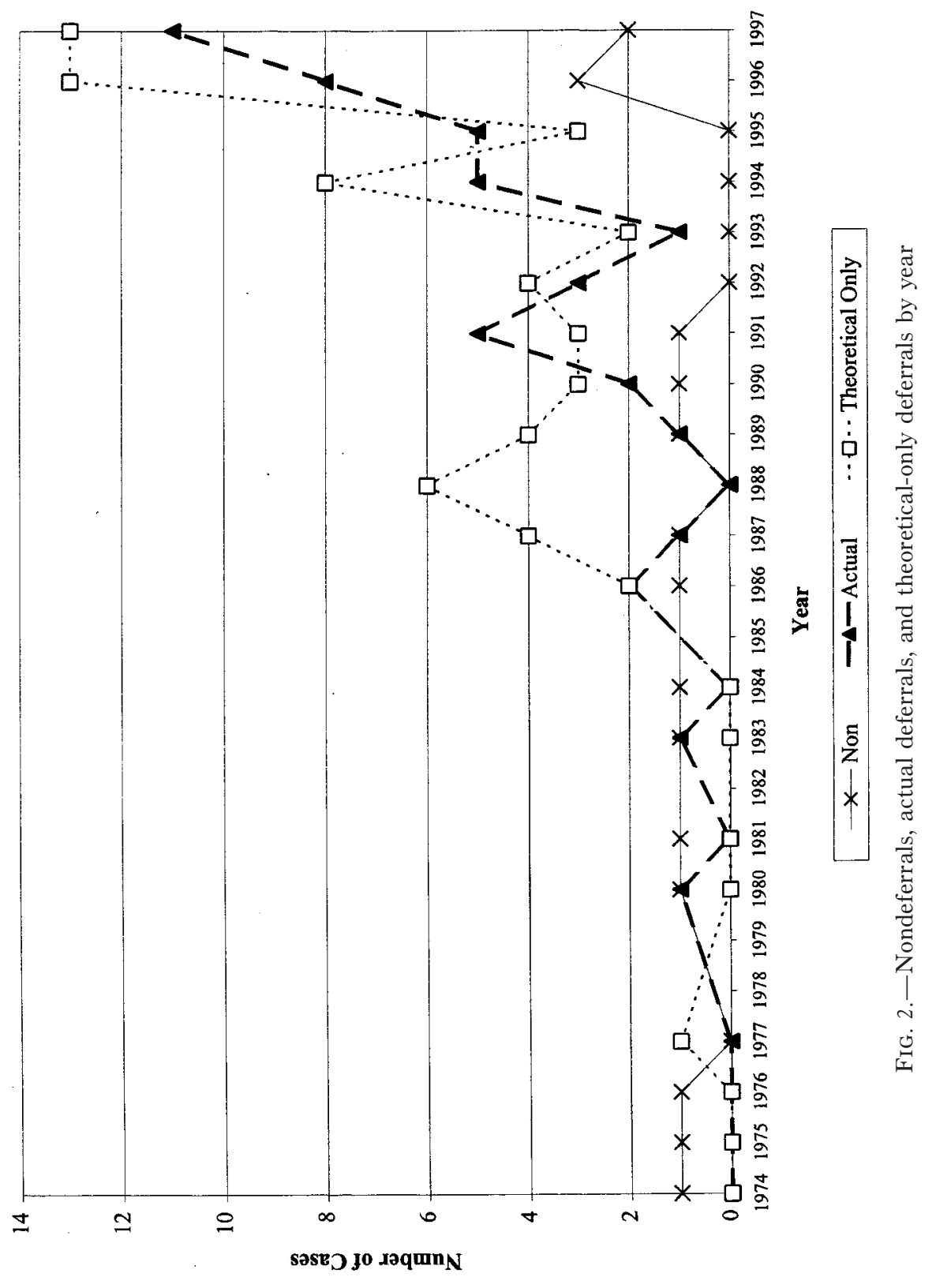


of the success of the grievance procedure defense, we use actual deferral as the dependent variable. And we use actual quality rather than theoretical quality as an independent variable since that variable better captures judicial attention to the quality of an organization's grievance procedure. Table 9 shows logit models predicting the log-likelihood of courts' actual deferrals to internal grievance procedures. Models 1 and 2 show the likelihood of judicial deferral for all cases in the sample; these models use only the year and actual quality variables. Models 3 and 4 show the likelihood of judicial deferral for post-Meritor cases only; for these models, we add the direct liability and Meritor cited variables, which are applicable only after Meritor.

Model 1, the basic model, shows a statistically significant positive effect of time on the likelihood of actual deferrals, which suggests that courts are becoming increasingly likely to defer to internal organizational grievance procedures in making decisions about liability. This is the critical model supporting our argument about endogeneity: courts are accepting - and reinforcing-stories about the rationality and legality of organizational grievance procedures.

Models 2-4 provide additional information about this time trend by identifying the types of cases in which deferrals are most likely to occur. Model 2, which still applies to the entire sample, shows that in making these decisions courts are paying (at least some) attention to the quality of internal grievance procedures. Although courts are unlikely to have knowledge about the key ways in which internal organizational grievance procedures differ from legal forums (Edelman et al. 1993), this finding suggests that courts at least attempt to follow Meritor's guidance that poor or sham grievance procedures cannot offer protection to employers.

Model 3 replicates model 2 for the post-Meritor cases only, and model 4 adds direct liability and whether Meritor is cited to the model. In the post-Meritor years, the year variable is statistically significant even with the control variables, suggesting a continuing institutionalization of courts' tendency to defer to internal organizational grievance procedures. Judicial attention to the quality of the internal grievance procedure also significantly predicts actual deferrals. ${ }^{30}$

Model 4 adds the direct liability variable, which measures whether the case was a hostile work environment or racial harassment case, in which

\footnotetext{
${ }^{30}$ Cross-tabulations reveal that of the 78 cases where courts paid attention to the quality of the grievance procedure, there were 41 actual deferrals, whereas out of the 51 cases in which quality was not considered, there were only five actual deferrals. Moreover, all of those 41 deferrals were in cases where courts found the grievance procedures to be good. Since the courts' views of the quality of the grievance procedure were perfectly correlated with deferral, we could not use a variable measuring whether actual quality was considered and found to be good in the logit analyses.
} 


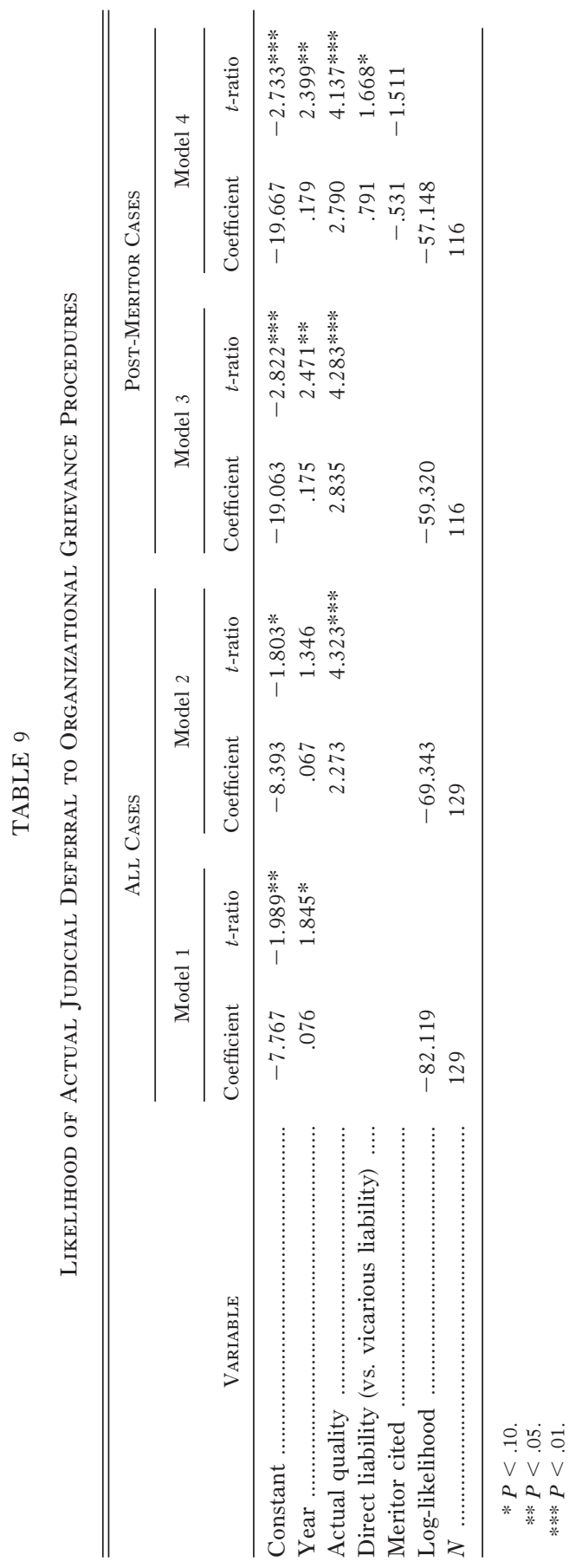


the direct liability standard applies (as opposed to a discrimination case or a quid pro quo sexual harassment case in which the vicarious liability standard applies). From a legal standpoint, only the direct liability standard gives courts the option of deferring to organizational grievance procedures since the vicarious liability standard holds that employers are liable for the acts of their agents irrespective of their knowledge of those acts. The variable attains only borderline statistical significance, suggesting that while deferrals are more likely in cases using the direct liability standard, this variable does not completely explain the time trend. The result must be interpreted with caution, however, because it was not clear whether the direct liability standard was used in sexual harassment cases involving mixed hostile work environment and quid pro quo claims. ${ }^{31}$

The Meritor-cited variable is negative, as expected, but not statistically significant. Thus, courts that cite Meritor are not significantly less likely to defer to organizational grievance procedures when attention to the quality of the grievance procedure is statistically controlled. This makes sense, since courts are likely to cite Meritor when they pay attention to the quality of the grievance procedure, whether or not they find it of sufficiently good quality to support a deferral.

Overall, tables 8 and 9 support our contention that judicial deferral to organizational grievance procedures takes place primarily in the 1990s, quite a few years after the personnel profession's initial claims of the value of internal grievance procedures. Further, although courts' recent tendencies to defer to internal grievance procedures can be explained in part by the introduction of direct liability principles into employment law, this does not mean that the law alone explains the new "truth" to the personnel professions' claims about the value of internal grievance procedures. There is nothing about direct liability principles that requires courts to defer to internal grievance procedures. Rather, those principles simply say that an employer who knew, or should have known, or approved of the acts of an agent may be held responsible. While the conceptual leap from direct liability theory to the relevance of organizational grievance procedures is not a huge one, it was greatly facilitated by the institutionalization of nonunion grievance procedures in organizations. That institutionalization, itself a response to the personnel professions' assumptions and claims about law, made grievance procedures seem like the most rational-and indeed the most natural mode-by which employers ought to find out about problems within their organizations.

\footnotetext{
${ }^{31}$ There were actual deferrals in only two cases that were quid pro quo-only cases and thus clearly used the vicarious liability standard. In cases involving both quid pro quo and hostile environment claims, it was often not clear whether the court used the direct or vicarious liability standard; we coded these cases "0" on the direct liability dummy variable.
} 
The flexibility and ambiguity inherent in the agency principle is evident in a passage from the Meritor opinion, in which the court relies on an amicus curiae brief of the EEOC, stating:

If the employer has an expressed policy against sexual harassment and has implemented a procedure specifically designed to resolve sexual harassment claims, and if the victim does not take advantage of that procedure, the employer should be shielded from liability absent actual knowledge of the sexually hostile environment (obtained, e.g., by the filing of a charge with the EEOC or a comparable state agency). In all other cases, the employer will be liable if it has actual knowledge of the harassment or if, considering all the facts of the case, the victim in question had no reasonably available avenue for making his or her complaint known to appropriate management officials. (Meritor Savings Bank v. Vinson, 26; citing brief for United States and EEOC as amici curiae)

That the EEOC must make a case for how agency principles should be interpreted in the context of hostile environment cases - and that Meritor cites the EEOC brief in its opinion on what agency principles meanshow that there agency principles do not require courts to defer to internal grievance procedures. Instead, employers like Meritor Savings Bank raise the grievance procedure defense because of the institutionalized belief that grievance procedures constitute fair treatment and that they may insulate employers from liability. Both the EEOC and the Meritor court move from the legal language involving agency principles to the importance of organizational policies and grievance procedures because of the same institutionalized beliefs. In this way, organizational policies and practices influence the construction of law in organizational settings. Courts give weight to organizational grievance procedures because ideologies of rationality suggest that these procedures constitute a reasonable alternative to litigation.

\section{RATIONAL MYTHS AND THE ENDOGENEITY OF LEGAL REGULATION}

To unravel the endogeneity of legal regulation, we have examined the rationalization of grievance procedures with data from the professional personnel literature, the courts, and a national sample of organizations. Over the past 30 years, EEO grievance procedures have become a standard and rationalized form of compliance with EEO law. The grievance procedure example illustrates the argument that ambiguous law generates strategic attempts at rational compliance, which cannot be viewed apart from institutionally constructed belief systems. The professions, influenced by the public legal order, construct stories about what forms of compliance will minimize interference by legal institutions. Strategically, 
rational organizations adopt these structures but often inject managerial goals into the legal form to make it better fit their objectives (Edelman et al. 1993).

Our analyses of the impact of organizational grievance procedures on legal complaints, and of judicial trends in deferring to organizational grievance procedures, show that the claims made by the personnel profession regarding the insulating power of grievance procedures were largely unfounded at the time they were made. Organizational grievance procedures appear to have no impact on the number of complaints to legal agencies and in fact increase the number of internal complaints. They may result in diversion of complaints from external to internal forums but probably only because EEO offices present in the same organization encourage employees to file more complaints and different types of complaints internally.

In addition, organizational grievance procedures had little legal value until recently and then primarily in cases where the direct liability standard has been adopted. Thus, the stories that the personnel profession created and disseminated about the rationality of organizational grievance procedures were not unreasonable ones; it took only small leaps in legal logic to believe that grievance procedures could provide insulation from the legal environment. But in fact, there was almost no basis in the law for these claims. It seems likely that the personnel professionals who were publishing on the topic simply "knew" the value of grievance procedures-because grievance procedures have been legitimated in organizational and socio-legal fields as institutions of legality and justice. Further, because the professions act as carriers of important information about the legal environment (Edelman 1992), organizations adopted grievance procedures without serious review of these claims.

The fictive status of these rational myths has now begun to change, however, because courts - as part of the same organizational and sociolegal fields-are influenced by the same set of institutionalized beliefs as other organizations (Edelman, in press). And as courts begin to legitimate grievance procedures, the professions also step up their message. ${ }^{32}$ Even since Meritor, the professions appear to construct straightforward stories about the rationality of grievance procedures, rather than delving into the

\footnotetext{
${ }^{32}$ Advice on the value of grievance procedures is not confined, moreover, to professional personnel journals or books; it is easily found on numerous sites on the World Wide Web. The Workforce Online site, for example, has a page titled "Minimize Risk by Investigating Complaints Promptly." The site advises employers that "Recent wrongful discharge and sexual harassment verdicts underscore an employer's liability for failing to provide for an effective means to resolve sexual and other harassment issues in the workplace. . . To avoid such risks, employers must develop and implement an effective method for employees to raise sexual harassment complaints."
} 
complexities and contradictions in the court decisions. For example, Alfred Feliu, shortly after the Meritor decision, wrote, "The existence of an internal system enhances both the appearance and reality of fairness of the company's actions in a later court proceeding. . . . The [Meritor] Court viewed the existence of an effective internal complaint procedure as a positiveand possibly dispositive-factor in defense of sexual harassment (and presumably other discrimination) claims" (Feliu 1987, pp. 91-92).

The Feliu quote, which appeared just after Meritor was decided, overstates the legal value of grievance procedures by suggesting that grievance procedures may be a "dispositive" factor in sexual harassment cases and "presumably in other discrimination cases," when in fact it is almost never dispositive and (even today) would probably not be an important factor in other discrimination cases.

The grievance procedure example, then, highlights the endogeneity of court decisions, professional norms, and organizational practices. Organizations create grievance procedures as evidence of fair treatment, and the professions make claims about the legal value of those procedures. As those claims become institutionalized, forming ideologies of rationality, courts recognize and construct the rationality of EEO grievance procedures by holding that, under some circumstances, these procedures constitute evidence of fair treatment and that employers may escape liability by adhering to their (effective) grievance resolution procedures. The professions, sometimes with greater enthusiasm than is perhaps warranted, filter and disseminate court decisions, which reinforce and legitimate organizations' initial structural responses to law. And the circle closes as organizations continue and elaborate their responses.

Of course, the organizational and legal treatment of grievance procedures has developed in the context of a highly ambiguous, politically contested, and weakly enforced set of laws. Had the law been clearer about the meaning of discrimination, or less politically contested, courts might defer less to the procedures and decisions of organizational actors. And, it may be the case that where expected enforcement is very weak, organizations may not even find it important to make symbolic gestures toward — or attempt to insulate themselves from - the legal environment. In fact, the pattern of EEO grievance procedure adoptions we find would be consistent with this argument since very few procedures appear until the early 1970s, a time at which EEO enforcement became somewhat more stringent.

Although we have focused on the development of the grievance procedure defense in Title VII actions, it is important to recognize that judicial deferral to organizational dispute resolution forums is not limited to federal discrimination cases. A 1996 case involving wrongful discharge in violation of an implied contract decided in the California court of appeals (Cotran v. Rollins Hudig Hall International, Inc., 57 Cal.Rptr.2d 129 
[1996]), for example, shows that judicial deferral to organizational forums is also occurring in implied contract wrongful discharge cases in state courts. ${ }^{33}$ The Cotran case is especially important because the court says explicitly that the result of an internal hearing need not be correct as long as the employer is acting in good faith. "To require an employer to be 'right' about the facts on which it bases its decision to terminate an employer is to interfere with the wide latitude an employer must have in making independent, good faith judgements about high-ranking employees without the threat of a jury second-guessing its business judgement. ... Where, as here, we are dealing with charges of sexual harassment, we believe the most we can reasonably ask of employers under these difficult circumstances is that they act responsibly and in good faith" (Cotran $v$. Rollins Hudig Hall International, Inc., 139-40).

Courts also defer, under some circumstances, to mandatory arbitration clauses. In 1991, the United States Supreme Court upheld arbitration clauses under the Federal Arbitration Act in Gilmer v. Interstate/Johnson Lane Corp. (111 Sup. Ct. 1647 [1991]). The court held that arbitration was no longer just a private means of resolving disputes between freely contracting parties but also an alternative forum for resolution of public statutory rights. Since then, a majority of the federal appellate circuits have held that Gilmer extends to mandatory arbitration of discrimination claims under employment contracts, and many employers are inserting mandatory arbitration clauses into employment contracts (Matthews 1997). And as in the case of organizational grievance procedures, numerous personnel articles and Web sites tout the rationality of mandatory arbitration.

Legislatures are also in some sense deferring to organizational realms. Both the 1990 Americans with Disabilities Act and the 1991 Civil Rights Act encourage employers to establish or participate in forms of alternative dispute resolution as a means of resolving complaints without resorting to litigation.

From a policy standpoint, judicial deferral to organizations-and the endogeneity of law generally-raises some concerns. Although Meritor warned that courts should defer only to effective grievance procedures, and our data suggest that many courts are heeding that warning, courts

\footnotetext{
${ }^{33}$ Ralph Cotran was fired from Rollins Hudig Hall for sexual harassment after two women used an internal grievance procedure to file sexual harassment charges against him and an internal investigation held that it was more likely than not that sexual harassment had occurred. Cotran then filed suit for wrongful termination claiming that there was an implied contract that he be terminated only for good cause. The jury in his wrongful termination suit found Cotran had not engaged in sexual harassment and awarded him $\$ 1,783,549$ for wrongful termination. The California court of appeals, however, overturned the verdict, finding that the lower court should not have overturned the findings of the organization's internal grievance procedure.
} 
are not likely to be aware of the many ways in which internal grievance forums may undermine legal rights. Even when employers have the best of intentions, the lack of formal due process protections that characterize internal grievance procedures, the different types of remedies offered by those forums, and the tendency of organizational complaint handlers to recast legal problems in managerial terms mean that legal rights are often transformed in the organizational context (Edelman et al. 1993). Further, employees may have good reasons for choosing not to use internal grievance procedures; for example, they may be legitimately concerned about biases of decision makers or retaliatory tactics of employers but may be unable to demonstrate these problems to a court. To the extent that courts defer to organizations without full awareness of the subtle pressures that characterize the workplace, legal ideals may be compromised. More generally, when courts adopt forms of compliance created within organizational fields, they run the risk of institutionalizing the very forms of discrimination that laws were originally designed to alleviate.

From a theoretical standpoint, our analysis of grievance procedures suggests an important corrective to the organizational literature on rationality. Although much of the literature debates whether rationality is "real," in the sense of providing market benefits (e.g., Williamson 1975), or socially constructed (e.g., Meyer and Rowan 1977), our study suggests that socially constructed rationality may over time produce market benefits as courts recognize and legitimate organizational practices and hold that they may protect organizations from liability.

Our example also elaborates the socio-legal literature on the symbolic nature of law (Edelman 1992; Stryker 1990, 1996) by illustrating how legal rules function less as absolute mandates than as rhetorical claims that acquire meaning through dialog across organizational, professional, and legal fields. That dialog operates as ideologies of rationality evolve within and flow across those fields, influencing ideas of justice as well as efficiency. Developments within each field spur reactions, interpretations, normative declarations, filtering processes, and organizational mimesis, all of which interact to construct not only organizational responses to law but the law itself.

\section{APPENDIX}

The Diffusion of EEO Grievance Procedures

Event-history models of the diffusion of EEO grievance procedures over time suggest that organizations did in fact heed the warnings and advice of the personnel profession. We estimated models of the form:

$$
r_{p}=\alpha_{p} e^{\beta x+\lambda_{p^{z} p}},
$$


TABLE A1

Determinants of the Creation of Specific Grievance Procedures

\begin{tabular}{|c|c|c|c|}
\hline Variables & Coefficient & Antilog & $t$-value \\
\hline \multicolumn{4}{|l|}{ Time-independent variables: } \\
\hline \multicolumn{4}{|l|}{ Sector: } \\
\hline 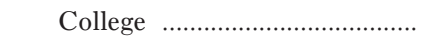 & $.75 * * *$ & 2.12 & 2.75 \\
\hline Government (business) ........... & $.94 * *$ & 2.56 & 2.17 \\
\hline 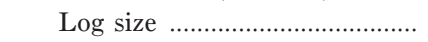 & $1.47 *$ & 1.15 & 1.89 \\
\hline \multicolumn{4}{|l|}{ 1964-76: } \\
\hline 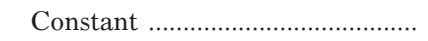 & $-6.63 * * *$ & .001 & -11.81 \\
\hline 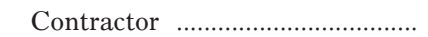 & $.91^{* *}$ & 2.49 & 2.05 \\
\hline 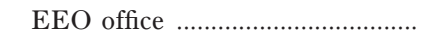 & $1.24 * *$ & 3.45 & 2.52 \\
\hline Lawsuit ........................................ & -8.29 & .0002 & -.18 \\
\hline \multicolumn{4}{|l|}{$1977-79:$} \\
\hline Constant .................................. & $-4.92 * * *$ & .007 & -9.31 \\
\hline 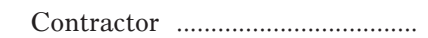 & .29 & 1.34 & .51 \\
\hline 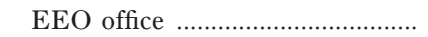 & $1.18 * *$ & 3.24 & 2.36 \\
\hline 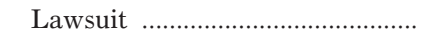 & -1.08 & .34 & -1.36 \\
\hline \multicolumn{4}{|l|}{ 1980-89: } \\
\hline 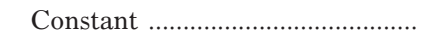 & $-5.49 * * *$ & .004 & -11.61 \\
\hline Contractor & -.39 & .68 & -1.09 \\
\hline 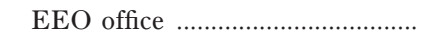 & .56 & 1.75 & 1.36 \\
\hline 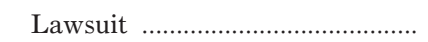 & $.93 * *$ & 2.54 & 2.54 \\
\hline
\end{tabular}

where $r_{p}$ represents the formation rate from the starting state (no structure) to the ending state (the creation of an internal EEO procedure) during period $p ; \alpha_{p}$ represents the constant term for period $p ; \beta x$ represents a vector of explanatory variables with effects that are not dependent on time period and their coefficients; and $\lambda_{p} z_{p}$ represents a vector of timedependent explanatory variables and their coefficients. ${ }^{34}$ Based on chisquare likelihood ratio tests of various period specifications, we allow the rate of procedure creation to vary across three historical periods: 196474, 1975-79, and 1980-89.

Table A1 in the appendix shows an event-history model of the diffusion of EEO grievance procedures. The coefficients give the effect of the vari-

\footnotetext{
${ }^{34}$ Event-history analysis is appropriate for modeling the sources of EEO grievance procedure creation because legal environments exert continuous pressure on organizations (Tuma and Hannan 1984; Allison 1984; Carroll 1983). The dependent variable is the rate of EEO grievance procedure creation, where the rate is defined as "the transitional probability over a unit of time where the unit is infinitesimal" (Carroll 1983).
} 
able on the log of the rate of special grievance procedure formation, while the antilogs of the coefficients give the multipliers for the base rate, or the relative risk of an EEO grievance procedure. The results for EEO grievance procedures are consistent with earlier analyses of the diffusion of institutional models, which addressed nonunion grievance procedures and general grievance procedures (Edelman 1990; Sutton et al. 1994). Organizational sector exerts a relatively strong effect on the rate of EEO grievance procedure formation. Government organizations are almost twice as likely as business organizations to create EEO grievance procedures, and colleges are also somewhat more likely than businesses to create such procedures. Organizational size has a marginally statistically significant effect on EEO grievance procedure formation, which may represent the greater visibility (Edelman 1992) or the greater financial and technical resources (Yeager 1991) of larger organizations.

During the first time period, federal contractor status and the presence of an EEO office predict EEO grievance procedure formation: both render organizations far more sensitive to their legal environments, and EEO offices provide a vehicle for the infusion of professional norms. Contractor status is no longer statistically significant during the 1980s, a period of waning civil rights enforcement. During the later period, experiencing a discrimination lawsuit is a positive predictor of EEO grievance procedure. The late effect of lawsuits may suggest that lawsuits motivate organizations to adopt institutionalized symbolic structures; if lawsuits motivated internal grievance procedures purely as a cost-reducing measure, one would expect a positive effect in the earlier periods as well.

The event-history findings, then, show that factors rendering organizations more sensitive to their legal environments-proximity to the public sphere, federal contractor status, the presence of an EEO office, and previous lawsuit experience-motivate a higher rate of EEO grievance procedure formation, especially during the late 1960s and 1970s when those procedures were spreading rapidly among organizations. These findings suggest that institutional environments provide an important source of ideas regarding the rationality of grievance procedures. The admonitions and advice of the legal and personnel professions, discussed above, illustrate an important mechanism by which these environments operate.

\section{REFERENCES}

Abbott, Andrew. 1988. The System of Professions. Chicago: University of Chicago Press. Allison, Paul D. 1984. Event History Analysis: Regression for Longitudinal Event Data. Beverly Hills, Calif.: Sage.

Baron, James N., Frank R. Dobbin, and P. Devereaux Jennings. 1986. "War and Peace: The Evolution of Modern Personnel Administration in U.S. Industry." American Journal of Sociology 92:350-83. 
Becker, Gary. 1971. The Economics of Discrimination, 2d ed. Chicago: University of Chicago Press.

Berger, Peter L., and Thomas Luckmann. 1967. The Social Construction of Reality. New York: Doubleday.

Carroll, Glenn R. 1983. "Dynamic Analysis of Discrete Dependent Variables: A Didactic Essay." Quality and Quantity 17:425-60.

Caspi, Avshalom, Bradley R. Entner-Wright, Terrie E. Moffitt, and Phil A. Silva. 1998. "Childhood Predictors of Unemployment in Early Adulthood." American Sociological Review 63:424-51.

Condon, Thomas J. 1985. "Use Union Methods in Handling Grievances." Personnel Journal 64:72-75.

Corzine, James E. 1967. "Structure and Utilization of a Grievance Procedure." Personnel Journal 46:484-89.

DiMaggio, Paul J. 1988. "Interest and Agency in Institutional Theory." Pp. 3-21 in Institutional Patterns and Organizations, edited by Lynne G. Zucker. Cambridge, Mass.: Ballinger.

DiMaggio, Paul J., and Walter W. Powell. 1983. "The Iron Cage Revisited: Institutional Isomorphism and Collective Rationality in Organizational Fields." American Sociological Review 48:147-60.

Dobbin, Frank R., Lauren B. Edelman, John W. Meyer, W. Richard Scott, and Ann Swidler. 1988. "The Expansion of Due Process in Organizations." Pp. 71-98 in Institutional Patterns and Organizations: Culture and Environment, edited by Lynn G. Zucker. Cambridge, Mass.: Ballinger.

Dobbin, Frank R., John R. Sutton, John W. Meyer, and W. Richard Scott. 1993. "Equal Employment Opportunity Law and the Construction of Internal Labor Markets." American Journal of Sociology 99:396-427.

Donahue, John J., III, and Peter Siegelman. 1991. "The Changing Nature of Employment Discrimination Litigation.” Stanford Law Review 43:983-1033.

Edelman, Lauren B. 1990. "Legal Environments and Organizational Governance: The Expansion of Due Process in the Workplace." American Journal of Sociology 95: $1401-40$

- 1992. "Legal Ambiguity and Symbolic Structures: Organizational Mediation of Law." American Journal of Sociology 97:1531-76.

—. In press. "Constructed Legalities: Socio-Legal Fields and the Endogeneity of Law." In Bending the Bars of the Iron Cage: Institutional Dynamics and Processes, edited by Walter W. Powell and Daniel Jones. Chicago: University of Chicago Press.

Edelman, Lauren B., Steven E. Abraham, and Howard S. Erlanger. 1992. "Professional Construction of the Legal Environment: The Inflated Threat of Wrongful Discharge Doctrine." Law and Society Review 26:47-83.

Edelman, Lauren B., Howard S. Erlanger, and John Lande. 1993. "Employers' Handling of Discrimination Complaints: The Transformation of Rights in the Workplace." Law and Society Review 27:497-534.

Edelman, Lauren B., and Stephen Petterson. 1999. "Symbols and Substance in Organizational Response to Civil Rights Law." In Research in Social Stratification and Mobility, vol. 17. Special issue on the future of affirmative action. In press.

Edelman, Lauren B., Stephen Petterson, Elizabeth Chambliss, and Howard S. Erlanger. 1991. "Legal Ambiguity and the Politics of Compliance: Affirmative Action Officers' Dilemma." Law and Policy 13:73-97.

Epstein, Richard A. 1992. Forbidden Grounds: The Case against Employment Discrimination Laws. Cambridge, Mass.: Harvard University Press.

Ewing, David W. 1982. "Due Process: Will Business Default?" Harvard Business Review 60:114-22.

Feliu, Alfred G. 1987. "Legal Consequences of Nonunion Dispute-Resolution Systems." Employee Relations Law Journal 13:83-103. 
Fuller, Sally Riggs. 1993. Symbolic Actions and Antics: Mechanisms for Shaping Organizational Reality. Doctoral dissertation. University of Wisconsin-Madison, School of Business.

Galanter, Marc. 1983. "Reading the Landscape of Disputes: What We Know and Don't Know (and Think We Know) about Our Allegedly Contentious and Litigious Society." UCLA Law Review 31:4-71.

. 1994. "Predators and Parasites: Lawyer-Bashing and Civil Justice." Georgia Law Review 28:633-81.

Gibbs, Jack P., and Glenn Firebaugh. 1985. "User's Guide to Ratio Variables.” American Sociological Review 50:713-22.

Heckman, James J. 1976. "The Common Structure of Statistical Models of Truncation, Sample Selection and Limited Dependent Variables and a Simple Estimator for Such Models." Annals of Economic and Social Measurement 5:475-92.

Heckman, James J., and Kenneth I. Wolpin. 1976. "Does the Contract Compliance Program Work? An Analysis of Chicago Data." Industrial and Labor Relations Review 29:544-64.

Hipp, Charles E., Jr. 1988. "Now You See It, Now You Don't: The 'Hostile Work Environment' after Meritor." American Business Law Journal 26:339-61.

Jacoby, Sanford M. 1985. Employing Bureaucracy: Managers, Unions, and the Transformation of Work in American Industry, 1900-1945. New York: Columbia University Press.

Konrad, Alison M., and Frank Linnehan. 1995. "Formalized HRM Structures: Coordinating Equal Employment Opportunity or Concealing Organizational Practices?" Academy of Management Journal 38 (3): 787-820.

Larson, Margali Sarfatti. 1977. The Rise of Professionalism. Berkeley: University of California Press.

Leonard, Jonathan S. 1984. "The Impact of Affirmative Action on Employment." Journal of Labor Economics 2:439-63.

1986. "The Effectiveness of Equal Employment Law and Affirmative Action Regulation." Research in Labor Economics 8:319-50.

Linenberger, Patricia, and Timothy J. Keaveny. 1981. "Sexual Harassment: The Employer's Legal Obligations." Personnel 58 (6): 60-68.

Little, Roderick J., and Donald Rubin. 1987. Statistical Analysis with Missing Data. New York: Wiley.

Lo Bosco, Maryellen. 1985. "Nonunion Grievance Procedures." Personnel 62:61-64.

Maddala, G. S. 1983. Limited Dependent and Qualitative Variables in Econometrics. Cambridge, Mass.: Cambridge University Press.

Matthews, Donna M. 1997. "Employment Law after Gilmer: Compulsory Arbitration of Statutory Antidiscrimination Rights." Berkeley Journal of Employment and Labor Law 18:347-87.

McDonald, John F., and Robert A. Moffitt. 1980. "The Uses of Tobit Analysis." The Review of Economics and Statistics 62:318-21.

Meyer, John W., and Brian Rowan. 1977. "Institutionalized Organizations: Formal Structure as Myth and Ceremony." American Journal of Sociology 83:340-63.

Mezias, Stephen J. 1990. "An Institutional Model of Organizational Practice: Financial Reporting at the Financial 200." Administrative Science Quarterly 31:431-57.

Oliver, Christine. 1991. "Strategic Responses to Institutional Processes." Academy of Management Review 16:145-79.

Panken, Peter M. 1984. "What Every Company Should Have: A Formal Employee Complaint Procedure." Management Review 73:42-45.

Pfeffer, Jeffrey. 1981. Power in Organizations. Cambridge, Mass.: Ballinger.

Pfeffer, Jeffrey, and Gerald R. Salancik. 1978. The External Control of Organizations. New York: Harper \& Row.

Posner, Richard A. 1986. Economic Analysis of Law, 3d ed. Boston: Little, Brown. 
Powell, Walter W. 1985. "The Institutionalization of Rational Organization: Review of Organizational Environments." Contemporary Sociology 14 (5): 564-66.

Powell, Walter W., and Paul J. DiMaggio, eds. 1991. The New Institutionalism in Organizational Analysis. Chicago: University of Chicago Press.

Roncek, Dennis W. 1992. "Learning More from Tobit Coefficients: Extending a Comparative Analysis." American Sociological Review 57:503-7.

Scott, W. Richard. 1983. "The Organization of Environments: Network, Cultural and Historical Elements." Pp. 129-53 in Organizational Environment: Ritual and Rationality, edited by John W. Meyer and W. Richard Scott. Beverly Hills, Calif.: Sage.

- 1987. Organizations: Rational, Natural, and Open Systems, 2d ed. Englewood Cliffs, N.J.: Prentice-Hall.

Scott, W. Richard, and John W. Meyer. 1983. "The Organization of Societal Sectors." Pp. 129-54 in Organizational Environments: Ritual and Rationality, edited by John W. Meyer and W. Richard Scott. Beverly Hills, Calif.: Sage.

Sewell, William H., Jr. 1992. "A Theory of Structure: Duality, Agency, and Transformation." American Journal of Sociology 98:1-29.

Stryker, Robin. 1990. "A Tale of Two Agencies: Class, Political-Institutional, and Organizational Factors Affecting State Reliance on Social Science." Politics and Society 18 (1): 101-41.

- 1994. "Rules, Resources, and Legitimacy Processes: Some Implications for Social Conflict, Order, and Change." American Journal of Sociology 99:847-910.

_ 1996. "Beyond Theory vs. History: Strategic Narrative and Sociological Explanation." Sociological Methods and Research 24:304-52.

Suchman, Mark. 1993. On Advice of Counsel: Legal and Financial Firms as Information Intermediaries in the Development of Silicon Valley. Doctoral dissertation. Stanford University, Department of Sociology.

Suchman, Mark C., and Lauren B. Edelman. 1996. "Legal-Rational Myths: Lessons for the New Institutionalism from the Law and Society Tradition." Law and Social Inquiry 21:903-41.

Sutton, John R., Frank Dobbin, John W. Meyer, and W. Richard Scott. 1994. "The Legalization of the Workplace." American Journal of Sociology 99:944-71.

Thompson, James D. 1967. Organizations in Action. New York: McGraw-Hill.

Tobin, James. 1958. "Estimation of Relationships for Limited Dependent Variables." Econometrica 26:24-36.

Tuma, Nancy, and Michael T. Hannan. 1984. Social Dynamics: Models and Methods. Orlando, Fla.: Academic Press.

Williamson, Oliver E. 1975. Markets and Hierarchies: Analysis and Antitrust Implications. New York: Free Press.

- 1979. "Transaction-Cost Economics: The Governance of Contractual Relations." Journal of Law and Economics 22:233-61.

—. 1981. "The Economics of Organization: The Transactions Cost Approach." American Journal of Sociology 87:548-77.

Winship, Christopher, and Robert D. Mare. 1992. "Models for Sample Selection Bias." Annual Review of Sociology 18:327-50.

Yeager, Peter. 1991. The Limits of Law: The Public Regulation of Private Pollution. Cambridge: Cambridge University Press.

Zucker, Lynn. 1977. "The Role of Institutionalization in Cultural Persistence." American Sociological Review 42:726-43.

. 1988. "Where Do Institutional Patterns Come From? Organizations as Actors in Social Systems." Pp. 23-49 in Institutional Patterns and Organizations: Culture and Environment, edited by Lynn G. Zucker. Cambridge, Mass.: Ballinger. 